\title{
132. Structural Comparison of Oligoribonucleotides and Their 2'-Deoxy-2'-fluoro Analogs by Heteronuclear NMR Spectroscopy
}

\author{
by Bernd Reif, Valentin Wittmann, Harald Schwalbe, and Christian Griesinger*, and \\ Karlheinz Wörner, Kerstin Jahn-Hofmann, and Joachim W. Engels
}

Institut für Organische Chemie, Universität Frankfurt, Marie-Curie-Str. 11, D-60439 Frankfurt

and Wolfgang Bermel

Bruker Analytik GmbH, Silberstreifen, D-76287 Rheinstetten

(19.VI.97)

1-(2'-Deoxy-2'-fluororibofuranosyl)pyrimidines were synthesized and incorporated into an RNA oligonucleotide to give $5^{\prime}-{ }^{\prime}\left[C_{f} G C_{r}\left(U_{f} U_{f} C_{T} G\right) G C_{F} G\right]-3^{\prime}\left(C_{f}\right.$ : short form of $C_{d^{1} f^{\prime} 2^{\prime}}=2^{\prime}$-deoxy-2'-fluorocytidine; $U_{f}$ : short form of $\mathrm{U}_{\mathrm{d}^{2} \mathrm{f}^{2}}=2^{\prime}$-deoxy-2'-fluorouridine). The oligomer was investigated by means of $U V$, $C D$, and NMR spectroscopy to address the question of how F-labels can substitute ${ }^{13} \mathrm{C}$-labels in the ribose ring. Through-space (NOE) and through-bond (scalar couplings) experiments were performed that make use of the ameliorated chemical-shift dispersion induced by ${ }^{19} \mathrm{~F}$ as an alternative heteronucleus. A comparison of the structures of fluorinated vs. unmodified oligomer is given. It turns out that the fluorinated oligonucleotide exists in a $14: 3$ equilibrium between a hairpin and a duplex conformation, in contrast to the unmodified oligonucleotide which predominantly adopts the hairpin conformation. Furthermore, the fluorinated hairpin structure adopts two distinct conformations that differ in the sugar conformation of the $U_{f}^{5}$ and $C_{f}^{6}$ nucleoside units, as detected by the ${ }^{19} \mathrm{~F}-\mathrm{NMR}$ chemical shifts. The role of the $2{ }^{\prime}-\mathrm{OH}$ group as stabilizing element in RNA secondary structure is discussed.

1. Introduction. - Since the pioneering studies of Duschinsky, Heidelberger, and coworkers [1] on the tumor-inhibitory effects of nucleosides of fluorinated pyrimidines, such as 5-fluorouracil, fluorinated nucleosides have been widely used as antimetabolites and mechanistic probes [2]. Due to its favorable NMR properties of $100 \%$ natural abundance, high sensitivity $\left(\gamma_{\mathbf{F}} / \gamma_{\mathbf{H}}=0.94\right)$, and high chemical-shift resolution [3], ${ }^{19} \mathrm{~F}$ labels served, e.g., as local NMR probes to study DNA/protein interactions [4], the solution structure [5] and thermal unfolding [6] of $E$. coli tRNA, and 5-fluorouracil metabolism [7]. Nucleosides with F-atoms in the carbohydrate ring are also of interest as antiviral agents [8]. The prime target for chemical modifications in the ribose moiety of RNA is the 2'-position. Hammerhead ribozymes containing 2 '-deoxy-2'-fluoronucleotides in combination with other structural modifications show a significantly increased stability against RNase digestion while the catalytic activity is fully conserved as compared to the wildtype [9]. 2'-Deoxy-2'-fluoronucleotides have been incorporated into antisense oligonucleotides to investigate regiospecific hydrolysis of RNA by RNase H [10] and to increase their binding affinities to RNA targets [11]. It is assumed that the increased stability of RNA - (fluorinated RNA) duplexes as compared to RNA - RNA duplexes is induced by the fact that $2^{\prime}$-deoxy-2'-fluoronucleosides prefer the $\mathrm{C}\left(3^{\prime}\right)$-endo 
sugar pucker and, therefore, stabilize the A-form of the duplex [11]. In general, RNA - RNA (A-form) duplexes are thermodynamically more stable than RNA - DNA $\left(\mathrm{A}, \mathrm{B}\right.$, or intermediate form) and DNA - DNA (B-form) duplexes, the latter having a $\mathrm{C}\left(2^{\prime}\right)$ endo sugar pucker [12]. The preference of 2'-deoxy-2'-fluoronucleotides and oligomers thereof to adopt an RNA-like $\left(\mathrm{C}\left(3^{\prime}\right)\right.$-endo) conformation rather than a DNA-like $\left(\mathrm{C}\left(2^{\prime}\right)\right.$ endo) has been demonstrated by NMR spectroscopy of monomers and dimers [13], X-ray structure analysis [14], and by CD spectroscopy [11] [15]. It is assumed that this stabilization of $\mathrm{C}\left(3^{\prime}\right)$-endo conformation results from the high electronegativity of the F-atom [16]. In substituting the $2^{\prime}-\mathrm{OH}$ group with an F-atom, a number of potentially important interactions are modified. Beside the increased electronegativity of the 2 '-substituent, the ability to form $\mathrm{H}$-bonds and the binding of cations will be changed by F-substitution. A detailed study of the influence of the 2 -F substitution on the conformation and dynamics of oligoribonucleotides as compared to their unmodified analogs by means of NMR spectroscopy has not yet been carried out. This includes those small structural units as, e.g., hairpins formed by oligoribonucleotides which contain nucleosides in both $\mathrm{C}\left(3^{\prime}\right)$ endo and $\mathrm{C}\left(2^{\prime}\right)$-endo conformations [17] and equilibria between these two conformations [18]. If it proved correct that oligoribonucleotides and their $2^{\prime}$-deoxy-2'-fluoro analogs resemble each other at least at specific sites of the molecule, $2^{\prime}$-deoxy-2'-fluoro RNA would be a suitable probe for conformational analysis bearing a number of advantages from the NMR spectroscopical point of view over unmodified RNA. 2'-Fluorination increases the chemical-shift dispersion of ${ }^{1} \mathrm{H}$ and ${ }^{13} \mathrm{C}$ resonances and introduces another well-resolved nucleus allowing heteronuclear isotope filtering experiments to be carried out. Furthermore, analysis of ${ }^{3} J\left(\mathrm{H}-\mathrm{C}\left(1^{\prime}\right), \mathrm{F}-\mathrm{C}\left(2^{\prime}\right)\right)$ and ${ }^{3} J\left(\mathrm{H}-\mathrm{C}\left(3^{\prime}\right), \mathrm{F}-\mathrm{C}\left(2^{\prime}\right)\right)$ coupling constants could provide an additional means for defining the sugar puckering compared to regular RNA. The chemical-shift range of ${ }^{19} \mathrm{~F}$ is also much bigger than that of ${ }^{1} \mathrm{H}$. Due to its strong dependence on stereoelectronic influences, analysis of ${ }^{19} \mathrm{~F}$-chemical shifts has been found to be also a sensitive probe for the conformation of pyranose rings [19] and might also serve as probe for ribose-ring conformation.

Here we present the synthesis and $C D$ and NMR spectroscopical investigation of the 10 mer RNA sequence $5^{\prime}-r\left[C_{f} G_{f}\left(U_{f} U_{f} C_{f} G\right) G C_{f} G\right]-3^{\prime}\left(C_{f}\right.$ : short form of $C_{d^{2}} f^{2^{\prime}}=2^{\prime}-d e-$ oxy-2'-fluorocytidine, $U_{f}$ : short form of $U_{\mathrm{d}^{2} \mathrm{f}^{\prime} \mathrm{f}^{\prime}}=2^{\prime}$-deoxy-2'-fluorouridine) and its unmodified RNA analog. C(UUCG)G RNA Hairpins have been studied in detail before and provide many reference data [20]. We have used NMR experiments relying on ${ }^{19} \mathrm{~F}$-labelling that facilitate the assignment of resonances and have developed new experiments for the determination of conformationally relevant parameters on the basis of 2 '-F-labelling of the sugar moiety. While the unmodified RNA forms a stable hairpin with a UV melting point of $72.7^{\circ}$, the fluorinated RNA has a melting point of $74.7^{\circ}$ and exists in two forms (duplex and hairpin) that undergo conformational exchange with a time constant of $0.28 \mathrm{~Hz}$ at a concentration of $1 \mathrm{~mm}$ and otherwise identical solution conditions. The structural transition is characterized by NMR including observation of exchange peaks in the ROESY spectra.

2. Results. - 2.1. Synthesis. 2'-Deoxy-2'-fluorouridine (2) [21] was prepared from commercially available $2,2^{\prime}$-anhydro-1- $(\beta$-D-arabinofuranosyl)uracil (1) [11] and further transformed into the $5^{\prime}-O$ - $\left(4,4^{\prime}\right.$-dimethoxytrityl)-protected $3^{\prime}$-(2-cyanoethyl diisopropylphosphoramidite) derivative 3 [11] [22] (Scheme 1) according to slightly modified litera- 
ture procedures. 2'-Deoxy-2'-fluorocytidine (5) [23] was synthesized from 2 via amination of the $C^{4}$-(3-nitro-1 $H$-1,2,4-triazolyl) intermediate 4 [24]. Selective benzoylation at $\mathrm{NH}_{2}-\mathrm{C}(4)$ of 5 [25] and further reactions following modified standard methodologies [22] gave phosphoramidite 6 [11].

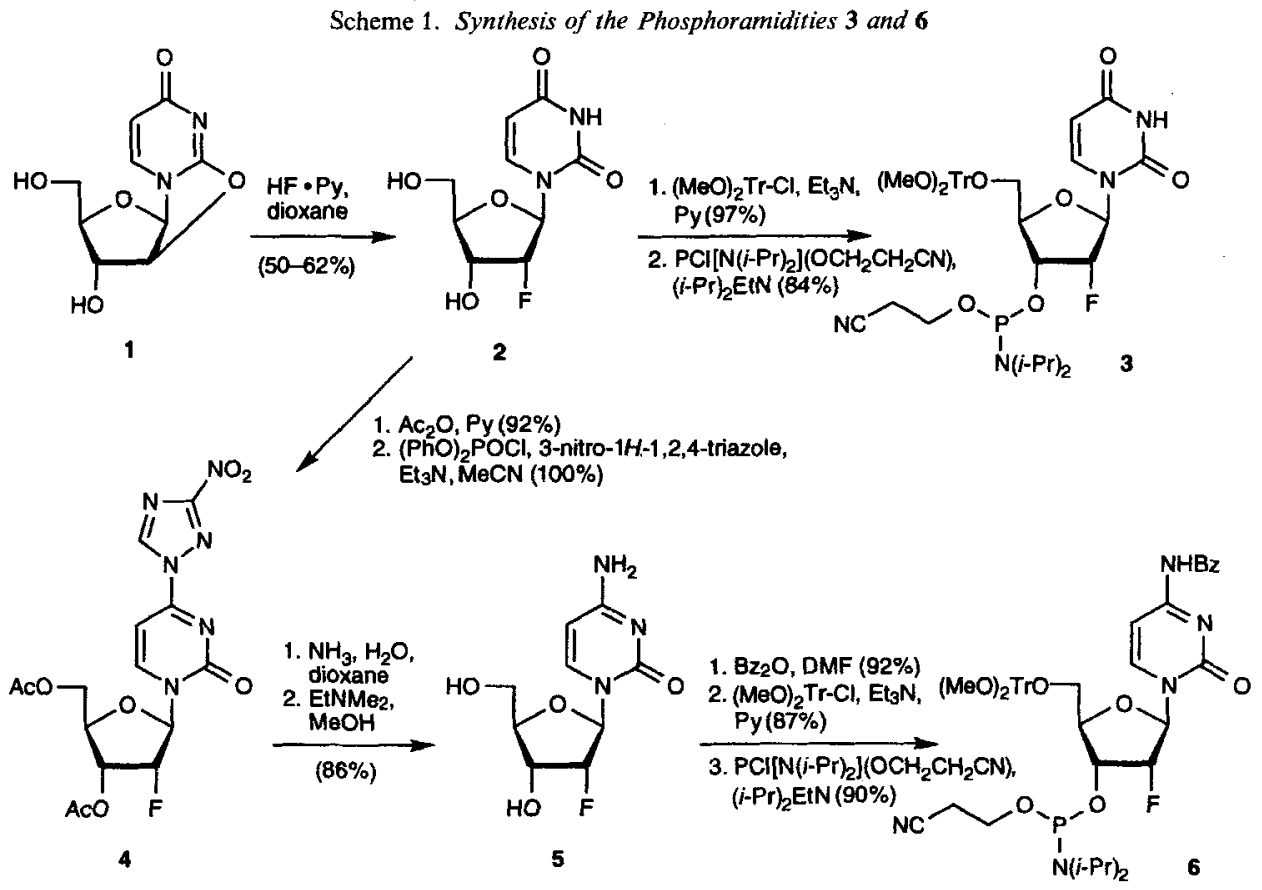

The RNA oligomers were synthesized on an Applied Biosystems 380 B and 394 nucleic-acid synthesizer, using phosphoramidite chemistry. The fully protected RNA oligomers were cleaved from the controlled pore glass (CPG) support manually with $32 \%$ aq. $\mathrm{NH}_{3}$ solution/abs. EtOH at $55^{\circ}$ for $12 \mathrm{~h}$. After evaporation, the 2 - $O$-silyl groups were removed under mild conditions with $\mathrm{Et}_{3} \mathrm{~N} \cdot 3 \mathrm{HF}$ within $24 \mathrm{~h}$ at $20^{\circ}$. The crude RNA oligomer was precipitated two times with $\mathrm{BuOH}$ at $-20^{\circ}$. The fully deprotected RNA oligomer was then analyzed and purified by ion-exchange HPLC. The pure oligomer was desalted using a Sephadex-G25 column.

2.2. CD Spectroscopy. Melting Curves for the Fluorinated and the Unfluorinated Oligomer. UV Melting curves of a $10 \mu \mathrm{M}$ sample were recorded at an absorption wavelength of $274 \mathrm{~nm}$ (see Fig. 1). Low hypochromicity of the fluorinated RNA oligomer during melting is also observed at $260 \mathrm{~nm}$. The melting point as determined by the first-order derivative of the UV absorption is observed at $74.7^{\circ}$, a temperature slightly above the melting point of the unmodified RNA oligomer. All characteristic thermodynamic parameters extracted from the UV melting curves are shown in Table 1. The remarkably low hypochromicity change of only $12.8 \%$ upon melting can be explained by a higher conformational order of the molten strand in the fluorinated as compared to the unmodified RNA oligomer. 
a)

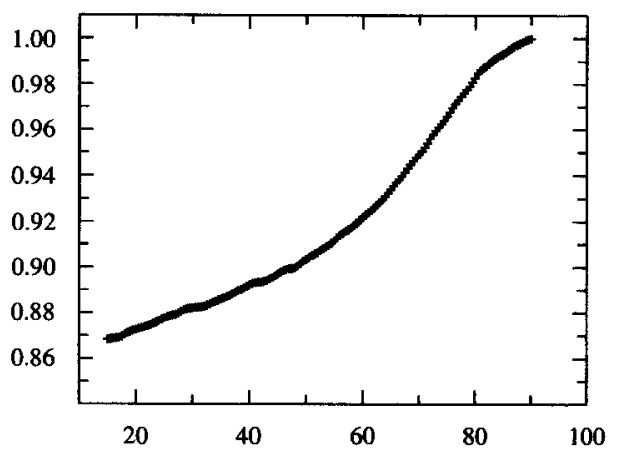

b)

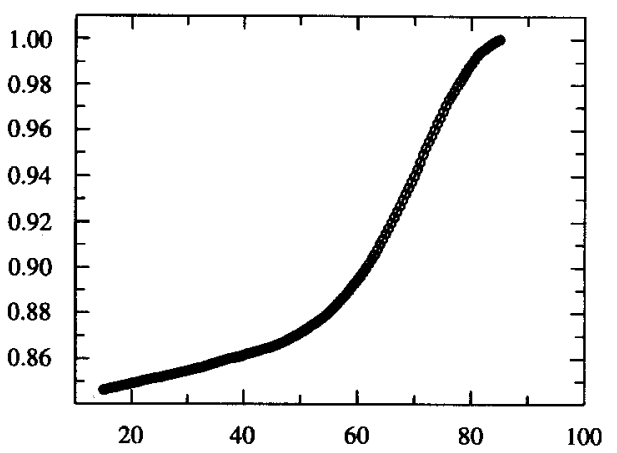

Fig. 1. UV Melting curves of a) the fluorinated $5^{\prime}-r\left[C_{f} G C_{f}\left(U_{f} U_{f} C_{f} G\right) G C_{f} G\right]-3^{\prime}$ and b) the unmodified $5^{\prime}-r$ /CGC(UUCG) GCG]-3' ( $\mathrm{C}_{\mathrm{f}}: 2^{\prime}$-deoxy-2'-fluorocytidine; $\mathrm{U}_{\mathrm{f}}$; 2'-deoxy-2'-fluorouridine)

Table 1. Thermodynamic Parameters $\left(T_{\mathrm{m}}, \Delta H^{0}, \Delta S^{0}, \Delta G^{0}\right.$, and hypochromicity $\left.h\right)$ for the $2^{\prime}$-Fluorinated Oligonucleotide $\left.5^{\prime}-r / C_{f} G C_{f}\left(U_{f} U_{f} C_{f} G\right) G C_{f} G\right]-3^{\prime}$ and the Unmodified Oligomer $5^{\prime}-r[C G C(U U C G) G C G]-3^{\prime}$

\begin{tabular}{|c|c|c|c|c|c|}
\hline & $T_{\mathrm{m}}\left[{ }^{\circ} \mathrm{C}\right]$ & $\Delta H^{0}[\mathrm{kcal} / \mathrm{mol}]$ & $\Delta S^{0}[$ e.u. $]$ & $\Delta G^{0}\left(37^{\circ}\right)[\mathrm{kcal} / \mathrm{mol}]$ & $h[\%]$ \\
\hline $5^{\prime}-\mathrm{r}\left[\mathrm{C}_{\mathrm{f}} \mathrm{GC}_{\mathrm{f}}\left(\mathrm{U}_{\mathrm{f}} \mathrm{U}_{\mathrm{f}} \mathrm{C}_{\mathrm{f}} \mathrm{G}\right) \mathrm{GC}_{\mathrm{f}} \mathrm{G}\right]-\mathbf{3}^{\prime}$ & 74.7 & -32.3 & -92.7 & -3.6 & 12.8 \\
\hline $5^{\prime}-\mathrm{r}[\mathrm{CGC}(\mathrm{UUCG}) \mathrm{GCG}]-3^{\prime}$ & 72.7 & -35.7 & -103.2 & -3.7 & 16.3 \\
\hline
\end{tabular}

The oligoribonucleotides exhibit at $20^{\circ}$ a CD spectrum (Fig. 2, solid lines) which shows characteristics of a hairpin [26]. There are two distinct positive Cotton effects for both oligoribonucleotides: for the unmodified tetraloop at 220.8 and $271.2 \mathrm{~nm}$ (Fig. 2, b) and for the 2'-fluorinated tetraloop at 223.6 and $272.2 \mathrm{~nm}$ (Fig. 2,a). At $80^{\circ}$, the CD spectra look like those of a single-stranded RNA with a negative (247.8 and $242.8 \mathrm{~nm}$, resp.) and a positive (275.6 and $273.6 \mathrm{~nm}$, resp.) Cotton effect (dashed lines).

a)

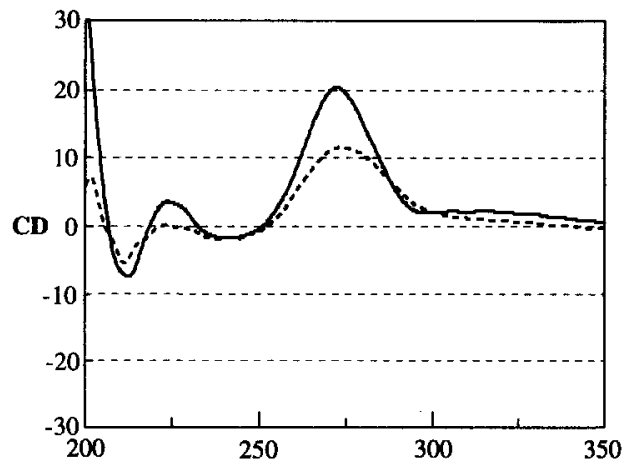

Wavelength[nm] b)

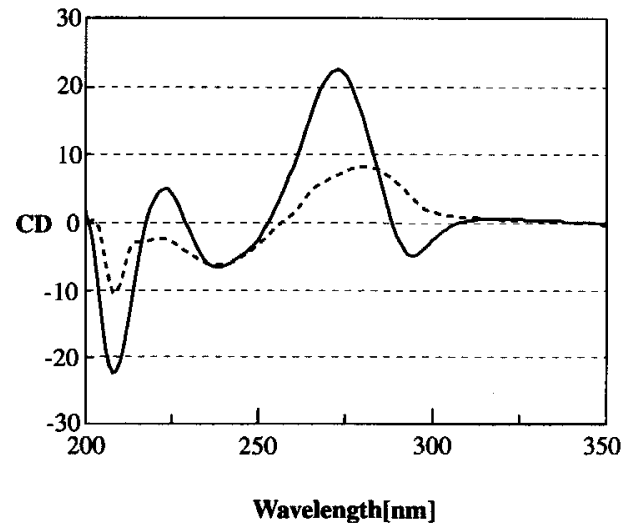

Fig. 2. CD Spectra of a) the fluorinated $\left.5^{\prime}-r / C_{f} G C_{f}\left(U_{f} U_{f} C_{f} G\right) G C_{f} G\right]-3^{\prime}$ and b) the unmodified $5^{\prime}-r / C G C$ (UUCG) GCG]-3'. Solid lines represent the spectrum at $20^{\circ}$, dashed lines correspond to the spectrum recorded at $80^{\circ}$. 
2.3. NMR Spectroscopy. 2.3.1. Assignment of the Fluorinated Oligonucleotide. The 2 -fluorination of oligoribonucleotides has a pronounced effect on the chemical-shift ranges of sugar protons and $\mathrm{C}$-atoms in oligonucleotides, which are summarized in Table 2 for $5^{\prime}-\mathrm{r}\left[\mathrm{C}_{\mathrm{f}} \mathrm{GC}_{\mathrm{f}}\left(\mathrm{U}_{\mathrm{f}} \mathrm{U}_{\mathrm{f}} \mathrm{C}_{\mathrm{f}} \mathrm{G}\right) \mathrm{GC}_{\mathrm{f}} \mathrm{G}\right]-3^{\prime}$. The $1 \mathrm{D}^{1} \mathrm{H}-\mathrm{NMR}$ spectra of this hexafluorinated RNA hairpin loop and of the corresponding unmodified RNA oligomer are compared in Fig. 3: While in the unmodified RNA hairpin loop, the chemical shifts of

Table 2. ${ }^{I} H-N M R$ Chemical-Shifts $\left([\mathrm{ppm}] ; 300 \mathrm{~K}, \mathrm{D}_{2} \mathrm{O}\right)$ of the Fluorinated RNA Oligonucleotide $\left.S^{\prime}-r / C_{f} G C_{f}\left(U_{f} U_{f} C_{f} G\right) G C_{f} G\right]-3^{\prime}$ for the Hairpin and the Duplex Conformation. All pyrimidine residues are fluorinated at the 2 -position; n.a. $=$ not assigned.

\begin{tabular}{|c|c|c|c|c|c|c|c|c|c|c|c|}
\hline & & $C_{f}^{1}$ & $\mathrm{G}^{2}$ & $\mathrm{C}_{\mathrm{f}}^{3}$ & $\mathrm{U}_{\mathrm{f}}^{4}$ & $U_{f}^{5}$ & $\mathrm{C}_{\mathrm{f}}^{\circ}$ & $G^{7}$ & $\mathrm{G}^{8}$ & $\mathrm{C}_{\mathrm{f}}^{9}$ & $\mathrm{G}^{10}$ \\
\hline \multirow[t]{5}{*}{ Hairpin: } & $\mathrm{H}-\mathrm{C}(6)$ or $\mathrm{H}-\mathrm{C}(8)$ & 8.103 & 7.890 & 7.496 & 7.743 & 7.853 & 7.690 & 7.912 & 8.258 & 7.652 & 7.768 \\
\hline & $\mathrm{H}-\mathrm{C}(5)$ & 6.108 & - & 5.426 & 5.815 & 5.812 & 5.764 & - & - & 5.442 & - \\
\hline & $\mathrm{H}-\mathrm{C}\left(1^{\prime}\right)$ & 5.885 & 5.909 & 5.955 & 6.127 & 5.989 & 6.028 & 6.007 & 4.626 & 5.955 & 5.975 \\
\hline & $\mathrm{H}-\mathrm{C}\left(2^{\prime}\right)$ & 5.459 & n.a. & 5.266 & 4.981 & 5.108 & 5.310 & 5.052 & n.a. & 5.266 & n.a. \\
\hline & $\mathrm{H}-\mathrm{C}\left(3^{\prime}\right)$ & 4.684 & n.a. & 4.392 & 4.652 & 4.873 & n.a. & 5.457 & n.a. & 4.602 & n.a. \\
\hline \multirow[t]{5}{*}{ Duplex: } & $\mathrm{H}-\mathrm{C}(6)$ or $\mathrm{H}-\mathrm{C}(8)$ & 8.103 & 7.876 & 7.617 & 7.758 & 7.880 & 7.767 & 7.607 & 7.429 & 7.559 & 7.682 \\
\hline & $\mathrm{H}-\mathrm{C}(5)$ & 6.108 & - & 5.369 & 5.750 & 5.657 & 5.596 & - & - & 5.375 & - \\
\hline & $H-C\left(1^{\prime}\right)$ & 5.885 & 5.883 & 5.898 & 6.060 & 5.773 & 6.100 & 5.645 & 5.789 & 5.885 & 5.939 \\
\hline & $\mathrm{H}-\mathrm{C}\left(2^{\prime}\right)$ & 5.459 & n.a. & 5.403 & 5.102 & 5.201 & 5.500 & n.a. & n.a. & 5.174 & n.a. \\
\hline & $\mathrm{H}-\mathrm{C}\left(3^{\prime}\right)$ & 4.680 & n.a. & 4.441 & 4.553 & n.a. & 4.643 & n.a. & n.a. & 4.585 & n.a. \\
\hline
\end{tabular}

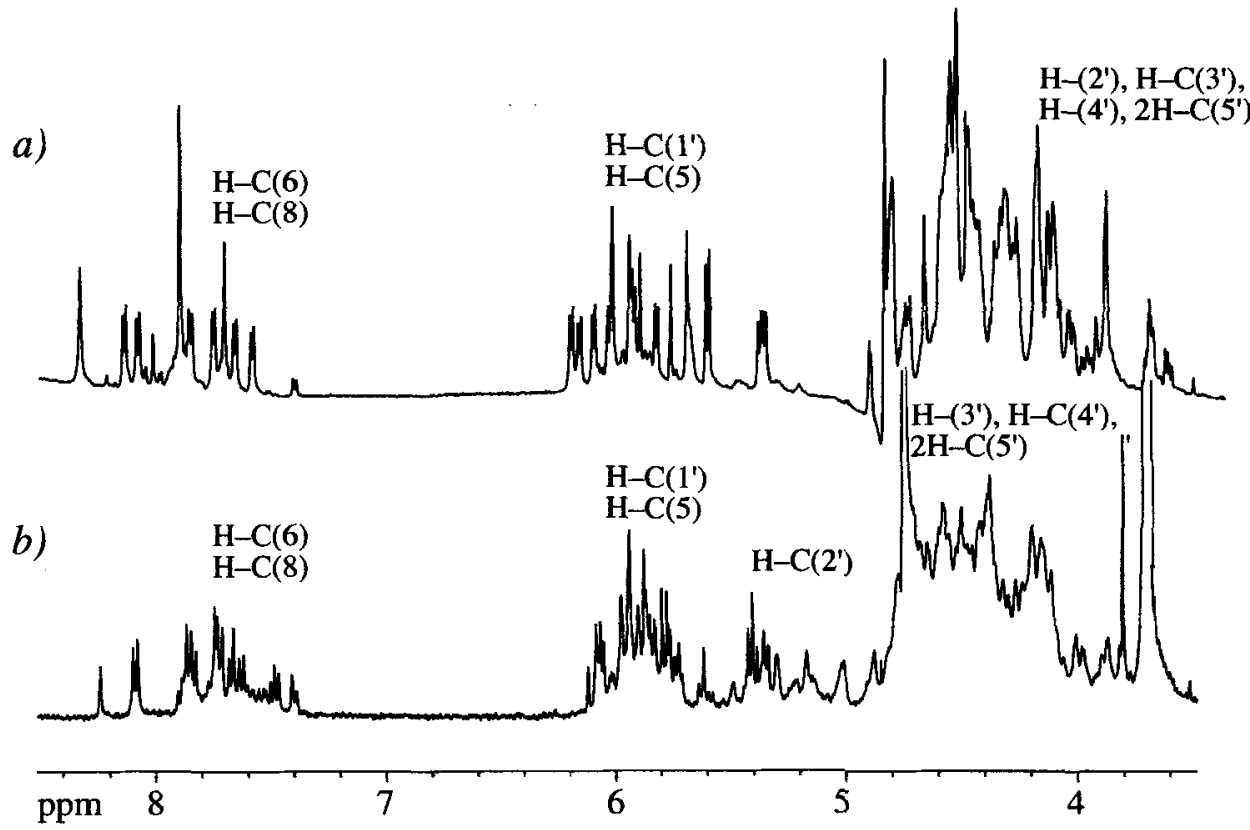

Fig. 3. Comparison of the $1 D^{1} H-N M R$ spectra $(600 \mathrm{MHz})$ of a) the unmodified $5^{\prime}-r / C G C$ (UUCG)GCGJ-3' and b) the 2'-fluorinated $5^{\prime}-r / C_{f} G C_{f}\left(U_{f} U_{f} C_{f} G\right) G C_{f} G J-3^{\prime}$. The $\mathrm{H}-\mathrm{C}\left(2^{\prime}\right)$ resonances of the $2^{\prime}$-deoxy-2'-fluororibose moieties are clearly separated from the $\mathrm{H}-\mathrm{C}\left(1^{\prime}\right)$ and $\mathrm{H}-\mathrm{C}\left(2^{\prime}\right), \mathrm{H}-\mathrm{C}\left(3^{\prime}\right), \mathrm{H}-\mathrm{C}\left(4^{\prime}\right), 2 \mathrm{H}-\mathrm{C}\left(5^{\prime}\right)$ resonances of the ribose moieties. 
the $\mathrm{H}-\mathrm{C}\left(2^{\prime}\right)$ region overlap with those of the $\mathrm{H}-\mathrm{C}\left(3^{\prime}\right), \mathrm{H}-\mathrm{C}\left(4^{\prime}\right)$, and $2 \mathrm{H}-\mathrm{C}\left(5^{\prime}\right)$ resonances (Fig. 3, b), the $\mathrm{H}-\mathrm{C}\left(2^{\prime}\right)$ region has moved by $c a .1 \mathrm{ppm}$ downfield in the fluorinated RNA oligomer and is, therefore, as well resolved as the $\mathrm{H}-\mathrm{C}\left(1^{\prime}\right)$ protons (Fig. 3,a).

a)

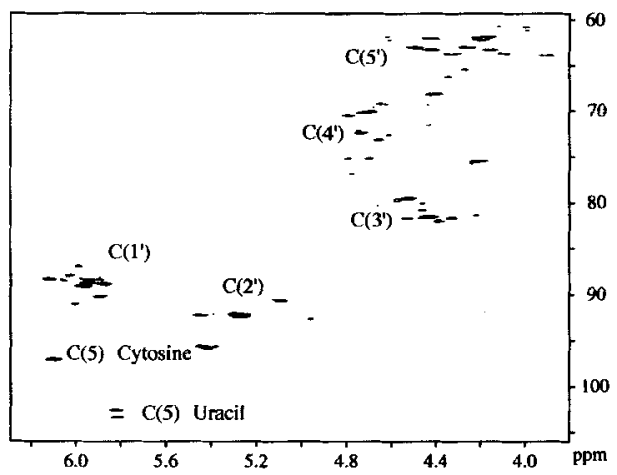

b)

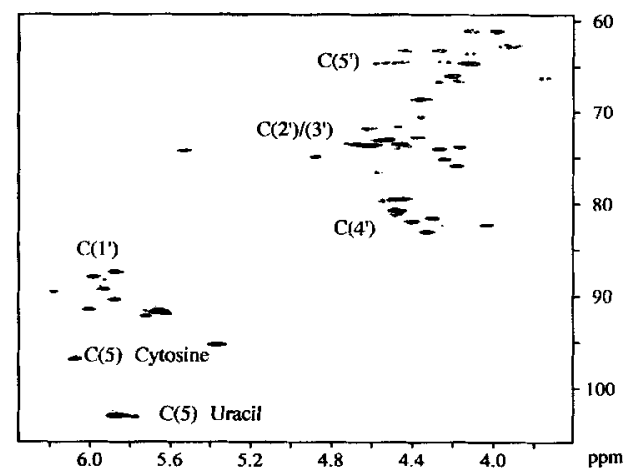

Fig. 4. Comparison of the ${ }^{1} H^{13}{ }^{13} \mathrm{C}-H S Q C$ spectra of a) the $2^{\prime}$-fluorinated $5^{\prime}-r\left[C_{f} G C_{f}\left(U_{f} U_{f} C_{f} G\right) G C_{f} G\right]-3^{\prime}$ and b) the unmodified $5^{\prime} r / C G C$ (UUCG $(G C G)-3^{\prime}$. The overlap in the $\mathrm{C}\left(2^{\prime}\right) / C\left(3^{\prime}\right)$ region of the unmodified oligomer is overcome upon fluorination, the $\mathrm{C}\left(2^{\prime}\right)$ resonances in the $\mathrm{C}$-dimension being shifted $c a .20 \mathrm{ppm}$ downfield in the 2'-fluorinated oligomer.

a)

b)

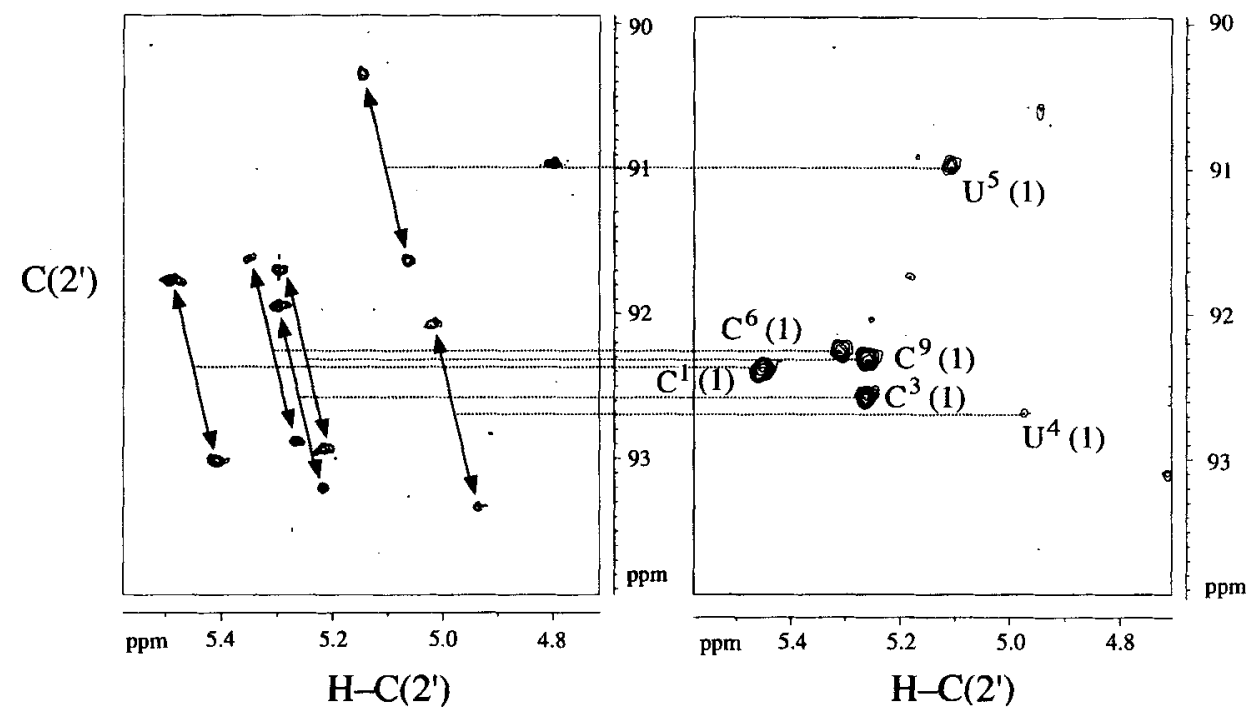

Fig. 5. ${ }^{1} \mathrm{H},{ }^{13} \mathrm{C}-\mathrm{HSQC}$ Spectrum of the $2^{\prime}$-fluorinated $\left.5^{\prime}-r / C_{f} G C_{f}\left(U_{f} U_{f} C_{f} G\right) G C_{f} G\right]-3^{\prime}$ in the $C\left(2^{\prime}\right) / H-C\left(2^{\prime}\right)$ region: a) without ${ }^{19} \mathrm{~F}$ decoupling during $\mathrm{t}_{1}$ and $\mathrm{t}_{2}$ (at $600 \mathrm{MHz}$ ) and b) with decoupling of ${ }^{19} \mathrm{~F}(\mathrm{at} 400 \mathrm{MHz})^{1}$ ). Arrows indicate the E.COSY splitting of the peaks due to the F-atom which acts as a passive nucleus. This yields directly the ${ }^{2} J\left(\mathrm{H}-\mathrm{C}\left(2^{\prime}\right), \mathrm{F}-\mathrm{C}\left(2^{\prime}\right)\right)$ coupling constants in $\omega_{2}$ and ${ }^{1} J\left(\mathrm{C}\left(2^{\prime}\right), \mathrm{F}-\mathrm{C}\left(2^{\prime}\right)\right)$ coupling constants in $\omega_{1}$, respectively ${ }^{3} J\left(\mathrm{H}-\mathrm{C}\left(1^{\prime}\right), \mathrm{F}-\mathrm{C}\left(2^{\prime}\right)\right)$ and ${ }^{2} J\left(\mathrm{C}\left(1^{\prime}\right), \mathrm{F}-\mathrm{C}\left(2^{\prime}\right)\right)$ (not shown). Numbers in parantheses after the nucleoside symbol indicate the conformation of the molecule $(1=$ hairpin, $2=$ duplex $)$.

1) For convenience, the nucleoside symbols $\mathrm{C}, \mathrm{G}$, and $\mathrm{U}$ of the unmodified oligomer are also used for the 2'-fluorinated oligomer in Figs. 5-12 and for the discussion referring to Figs. 8 and 9. 
Comparison of the ${ }^{13} \mathrm{C},{ }^{1} \mathrm{H}-\mathrm{HSQC}$ spectra of the native RNA hairpin and the fluorinated hairpin is shown in Fig. 4: the CH correlations of all sugar moieties are resolved in the fluorinated hairpin (Fig. 4, a). The level of incorporation of ${ }^{19} \mathrm{~F}$ can also be seen in the ${ }^{13} \mathrm{C},{ }^{1} \mathrm{H}$-HSQC spectrum which was recorded without and with ${ }^{19} \mathrm{~F}$ decoupling (Fig. 5, $a$ and $b$, resp.). The spin-1/2-isotope ${ }^{19} \mathrm{~F}$ has $100 \%$ natural abundance and causes an E. COSY [27] splitting marked by the displacement vector $J_{\mathrm{F}}=\left({ }^{1} J\left(\mathrm{C}\left(2^{\prime}\right), \mathrm{F}-\mathrm{C}\left(2^{\prime}\right)\right)\right.$, $\left.{ }^{2} J\left(\mathrm{H}-\mathrm{C}\left(2^{\prime}\right), \mathrm{F}-\mathrm{C}\left(2^{\prime}\right)\right)\right)$ in the coupled experiment (Fig. 5,a), which collapses in the decoupled experiment (Fig. 5,b). At the level of signal-to-noise chosen in this spectrum, all six fluorinated nucleosides of the hairpin conformation (1) are visible.

The ${ }^{19} \mathrm{~F},{ }^{1} \mathrm{H}-\mathrm{HSQC}$ spectrum (at $600 \mathrm{MHz}$ ) of $5^{\prime}-\mathrm{r}\left[\mathrm{C}_{\mathrm{f}} \mathrm{GC}_{\mathrm{f}}\left(\mathrm{U}_{\mathrm{f}} \mathrm{U}_{\mathrm{f}} \mathrm{C}_{\mathrm{f}} \mathrm{G}\right) \mathrm{GC}_{\mathrm{f}} \mathrm{G}\right]-3^{\prime}$ shows high resolution (Fig. 6). The ${ }^{19} \mathrm{~F}$ resonances are well resolved and sharp and spread over $2.5 \mathrm{ppm}$. A correlation of all $\mathrm{H}-\mathrm{C}\left(1^{\prime}\right), \mathrm{H}-\mathrm{C}\left(2^{\prime}\right)$, and $\mathrm{H}-\mathrm{C}\left(3^{\prime}\right)$ resonances to that of the F-atom in the corresponding sugar moiety is observed, some of which become only visible at a lower plot level than that chosen for the spectrum shown in Fig. 6. The intensity of the correlations reflects the size of the ${ }^{n} J(\mathrm{H}, \mathrm{F})$ coupling constants, which are summarized in Table 3. The ${ }^{19} \mathrm{~F},{ }^{1} \mathrm{H}-\mathrm{HSQC}$ spectrum $(600 \mathrm{MHz})$ contains two sets of

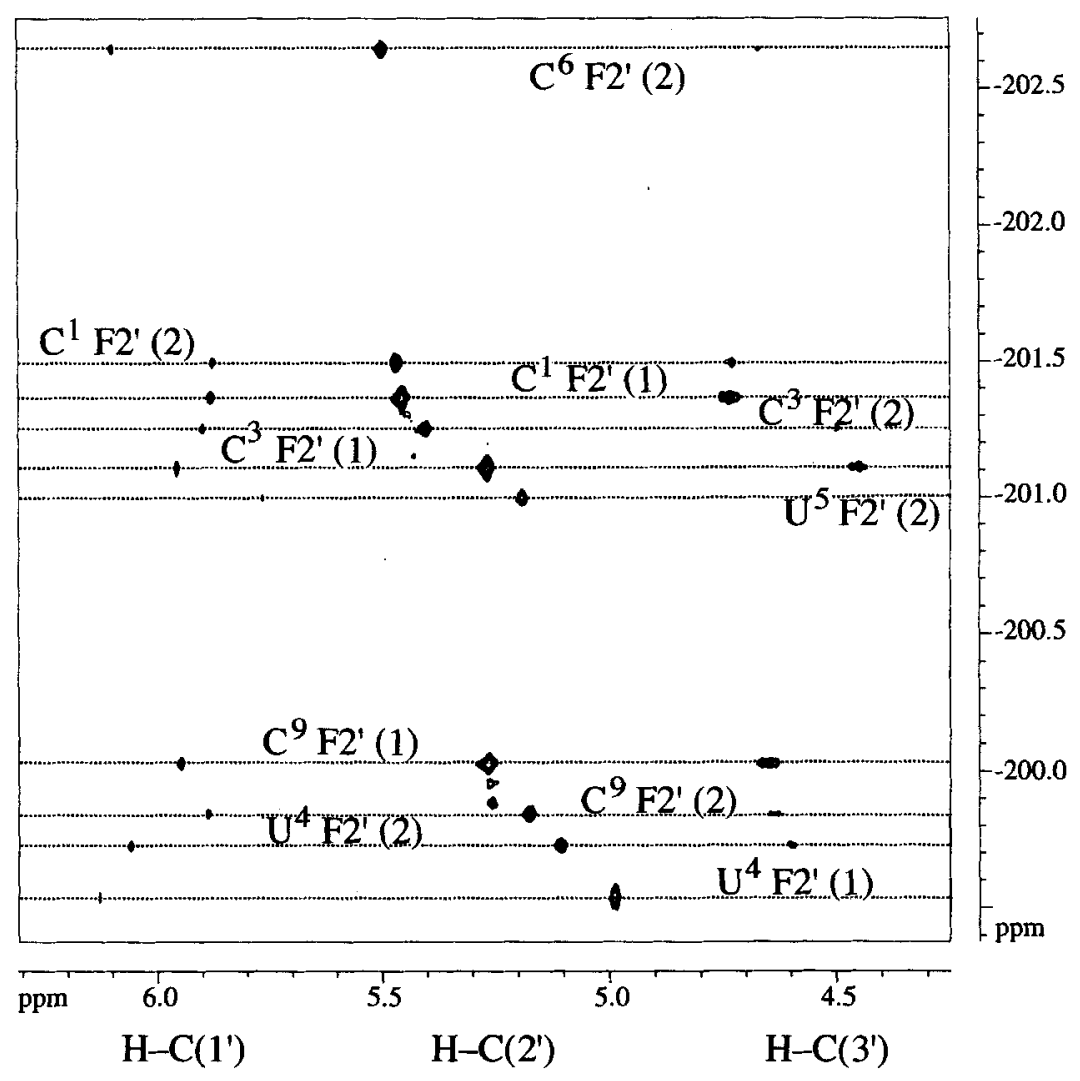

Fig. 6. ${ }^{1} H^{1,{ }^{19}} \mathrm{~F}-\mathrm{HSQC}$ Spectrum (600 MHz) of the $2^{\prime}$-fluorinated $\left.5^{\prime}-r\left(C_{f} G C_{f}\left(U_{f} U_{f} C_{f} G\right) G C_{f} G\right]-3^{\prime 1}\right)$. The assignment of the fluorinated pyrimidine residues is indicated by horizontal dashed lines $\left(\mathrm{F} 2^{\prime}=\mathrm{F}-\mathrm{C}\left(2^{\prime}\right)\right)$. The respective conformation is given in parentheses $(1=$ hairpin, $2=$ duplex $)$. 
Table 3. Measured Scalar Coupling Constants $[\mathrm{Hz}]$ in the Fluorinated Oligonucleotide $\left.5^{\prime}-r / C_{f} G C_{f}\left(U_{f} U_{f} C_{f} G\right) G C_{f} G\right)-3^{\prime}$ for the Hairpin and Duplex Conformation. ${ }^{3} J\left(\mathrm{H}-\mathrm{C}\left(1^{\prime}\right), \mathrm{H}-\mathrm{C}\left(2^{\prime}\right)\right)$ coupling constants in purine nucleotides are smaller than $1 \mathrm{~Hz}$.

\begin{tabular}{|c|c|c|c|c|c|c|c|}
\hline & & $\mathrm{C}_{\mathrm{f}}^{1}$ & $\mathrm{C}_{\mathrm{f}}^{3}$ & $\mathrm{U}_{\mathrm{f}}^{4}$ & $\mathbf{U}_{\mathrm{f}}^{5}$ & $\mathrm{C}_{\mathrm{f}}^{6}$ & $\mathrm{C}_{\mathrm{f}}^{9}$ \\
\hline \multirow[t]{6}{*}{ Hairpin (1): } & ${ }^{3} J\left(\mathrm{H}-\mathrm{C}\left(1^{\prime}\right), \mathrm{H}-\mathrm{C}\left(2^{\prime}\right)\right)$ & 0.1 & 0.1 & 1.3 & 4.0 & 3.3 & 0.7 \\
\hline & ${ }^{3} J\left(\mathrm{H}-\mathrm{C}\left(2^{\prime}\right), \mathrm{H}-\mathrm{C}\left(3^{\prime}\right)\right)$ & - & 2.8 & - & - & - & 2.8 \\
\hline & ${ }^{3} J\left(\mathrm{H}-\mathrm{C}\left(3^{\prime}\right), \mathrm{H}-\mathrm{C}\left(4^{\prime}\right)\right)$ & - & 9.7 & - & - & - & 9.6 \\
\hline & ${ }^{1} J\left(\mathrm{~F}-\mathrm{C}\left(2^{\prime}\right), \mathrm{C}\left(2^{\prime}\right)\right)$ & 191.7 & 194.0 & 191.2 & 195.0 & 193.3 & 194.0 \\
\hline & ${ }^{2} J\left(\mathrm{~F}-\mathrm{C}\left(2^{\prime}\right), \mathrm{H}-\mathrm{C}\left(2^{\prime}\right)\right)$ & -51.6 & -51.6 & -51.4 & -50.8 & -51.7 & -51.8 \\
\hline & ${ }^{3} J\left(\mathrm{~F}-\mathrm{C}\left(2^{\prime}\right), \mathrm{H}-\mathrm{C}\left(1^{\prime}\right)\right)$ & 13.4 & 14.1 & 15.8 & 14.0 & 15.6 & 13.5 \\
\hline \multirow[t]{5}{*}{ Duplex (2): } & ${ }^{3} J\left(\mathrm{H}-\mathrm{C}\left(1^{\prime}\right), \mathrm{H}-\mathrm{C}\left(2^{\prime}\right)\right)$ & 0.1 & 0.1 & 0.9 & $<1$ & 0.5 & 0.8 \\
\hline & ${ }^{3} J\left(\mathrm{H}-\mathrm{C}\left(2^{\prime}\right), \mathrm{H}-\mathrm{C}\left(3^{\prime}\right)\right)$ & 3.2 & - & - & - & - & - \\
\hline & ${ }^{3} J\left(\mathrm{H}-\mathrm{C}\left(3^{\prime}\right), \mathrm{H}-\mathrm{C}\left(4^{\prime}\right)\right)$ & 10.2 & - & - & - & - & - \\
\hline & ${ }^{2} J\left(\mathrm{~F}-\mathrm{C}\left(2^{\prime}\right), \mathrm{H}-\mathrm{C}\left(2^{\prime}\right)\right)$ & -51.6 & -51.6 & -52.1 & -51.6 & -52.4 & -51.7 \\
\hline & ${ }^{3} J\left(\mathrm{~F}-\mathrm{C}\left(2^{\prime}\right), \mathrm{H}-\mathrm{C}\left(1^{\prime}\right)\right)$ & 13.3 & 13.2 & 14.6 & 14.0 & 13.8 & 14.2 \\
\hline
\end{tabular}

resonances for the fluorinated stem nucleosides $\mathrm{C}_{\mathrm{f}}^{1}, \mathrm{C}_{\mathrm{f}}^{3}, \mathrm{U}_{\mathrm{f}}^{4}$, and $\mathrm{C}_{\mathrm{f}}^{9}$ stemming from two slowly interconverting conformations, namely a hairpin (1) and a duplex conformation (2) of the fluorinated oligomer. The ${ }^{19} \mathrm{~F}$-NMR chemical shifts of nucleosides in the stem of both the duplex and the hairpin conformation are not more than $0.4 \mathrm{ppm}$ apart. ${ }^{19} \mathrm{~F},{ }^{1} \mathrm{H}$ Correlations of the two nucleosides $\mathrm{U}_{\mathrm{f}}^{5}$ and $\mathrm{C}_{\mathrm{f}}^{6}$, populating also the $\mathrm{C}\left(2^{\prime}\right)$-endo
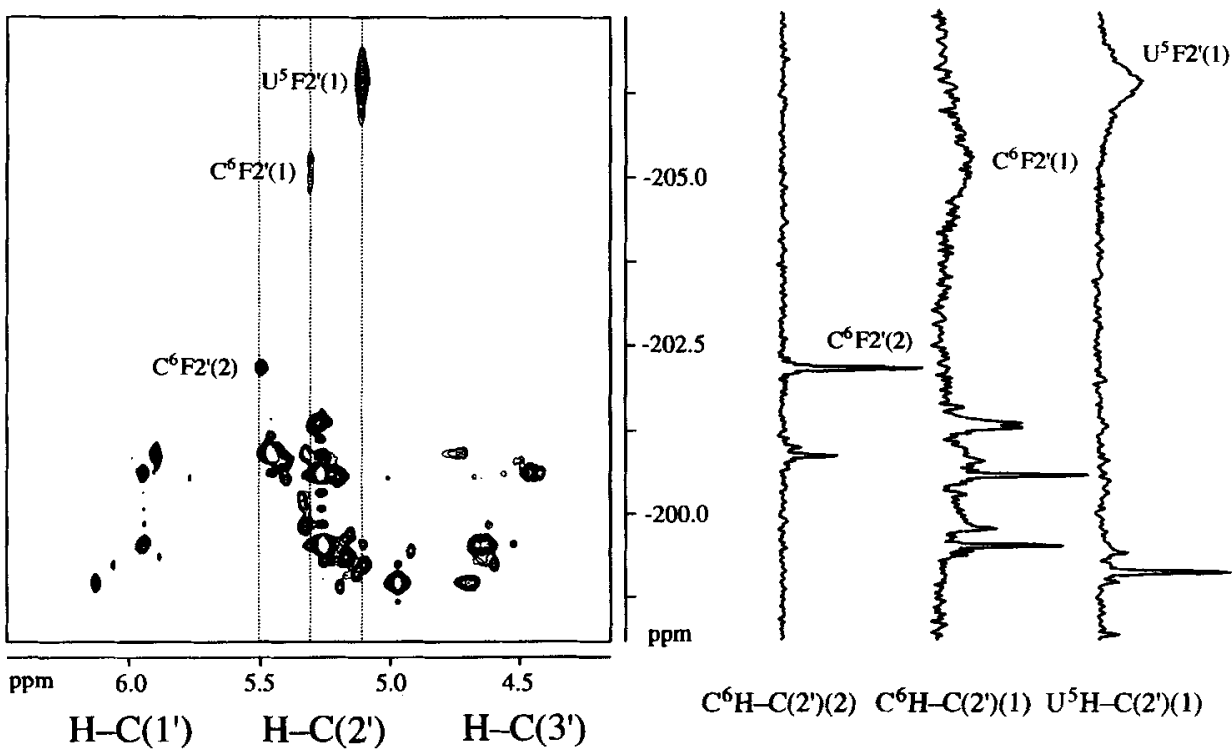

$\mathrm{C}^{6} \mathrm{H}-\mathrm{C}\left(2^{\prime}\right)(2) \mathrm{C}^{6} \mathrm{H}-\mathrm{C}\left(2^{\prime}\right)(1) \mathrm{U}^{5} \mathrm{H}-\mathrm{C}\left(2^{\prime}\right)(1)$

Fig. 7. ${ }^{1} H^{19}{ }^{19} \mathrm{~F}-H S Q C$ Spectrum $(400 \mathrm{MHz})$ of the $2^{\prime}$-fiturinated $\left.5^{\prime}-r / C_{f} G C_{f}\left(U_{f} U_{f} C_{f} G\right) G C_{f} G /-3^{\prime}\right)$. In contrast to the same spectrum at $600 \mathrm{MHz}$ (see Fig. O), also the F-resonances of $\mathrm{U}^{5}(1)$ and $\mathrm{C}^{6}(1)$ are visible $\left(F 2^{\prime}=\mathrm{F}-\mathrm{C}\left(2^{\prime}\right)\right)$. On the right, columns through resonances of $\mathrm{C}^{6} \mathrm{H}-\mathrm{C}\left(2^{\prime}\right)(2), \mathrm{C}^{6} \mathrm{H}-\mathrm{C}\left(2^{\prime}\right)(1)$, and $\mathrm{U}^{5} \mathrm{H}-\mathrm{C}\left(2^{\prime}\right)(1)$ are shown. Data were apodized using a line broadening of $20 \mathrm{~Hz}$ in the indirect dimension. 
conformation (vide infra) in the hairpin are missing at $600 \mathrm{MHz}$; they become observable only at $400 \mathrm{MHz}$ as very broad resonances with line widths of $150 \mathrm{~Hz}$ for $U_{\mathrm{f}}^{5}$ and $525 \mathrm{~Hz}$ for $\mathrm{C}_{\mathrm{f}}^{6}$. The $2 \mathrm{D}$ correlation as well as $1 \mathrm{D}$ columns at specific proton frequencies are shown in Fig. 7. This finding is in agreement with an exchange process on a submillisecond time scale for the hairpin. It is restricted to the hairpin since no such effect is observed for $U_{f}^{5} F-C\left(2^{\prime}\right)(2)$ and $C_{f}^{6} F-C\left(2^{\prime}\right)(2)$ duplex resonances. The line width of duplex resonances are not changed at all. The ${ }^{1} \mathrm{H}$ and ${ }^{13} \mathrm{C}$ resonances do not appear to be broadened indicating that the exchange process is much faster than the respective chemical-shift differences of the two interconverting conformations.

The rate of interconversion between the hairpin and the duplex conformation of $\left.5^{\prime}-\mathrm{r}_{\mathrm{f}} \mathrm{C}_{\mathrm{f}} \mathrm{GC}_{\mathrm{r}}\left(\mathrm{U}_{\mathrm{f}} \mathrm{U}_{\mathrm{f}} \mathrm{C}_{\mathrm{f}} \mathrm{G}\right) \mathrm{GC}_{\mathrm{f}} \mathrm{G}\right]-3^{\prime}$ can be determined from a quantitative evaluation of the ROESY [28] spectra (Fig. 8). Cross peaks originating from exchange between two conformers have the same sign as diagonal peaks and are observed between, e.g., $\mathrm{U}^{4} \mathrm{H}-\mathrm{C}\left(2^{\prime}\right)(1)$ (hairpin, conformation 1) and $\mathrm{U}^{4} \mathrm{H}-\mathrm{C}\left(2^{\prime}\right)(2)$ (duplex, conformation 2) (marked with circles in Fig. 8) ${ }^{1}$ ). The same resonances show also negative cross peaks to $\mathrm{U}^{4} \mathrm{H}-\mathrm{C}\left(1^{\prime}\right)(1)$ and $\mathrm{U}^{4} \mathrm{H}-\mathrm{C}\left(1^{\prime}\right)(2)$, respectively, which are due to NOE contacts within one molecule. The diagonal-peak-intensity (conformation 2) to cross-peak-intensity (conformation 1) ratio is 19.0:0.82 which indicates, for a mixing time of $150 \mathrm{~ms}$ in the ROESY spectrum, that the exchange rate of hairpin to duplex is $c a .0 .28 \mathrm{~Hz}$. The hairpin population can be determined to be $82 \%$, whereas the population of the duplex is $18 \%$, resulting in a ratio of resonance intensities of $7: 3$.

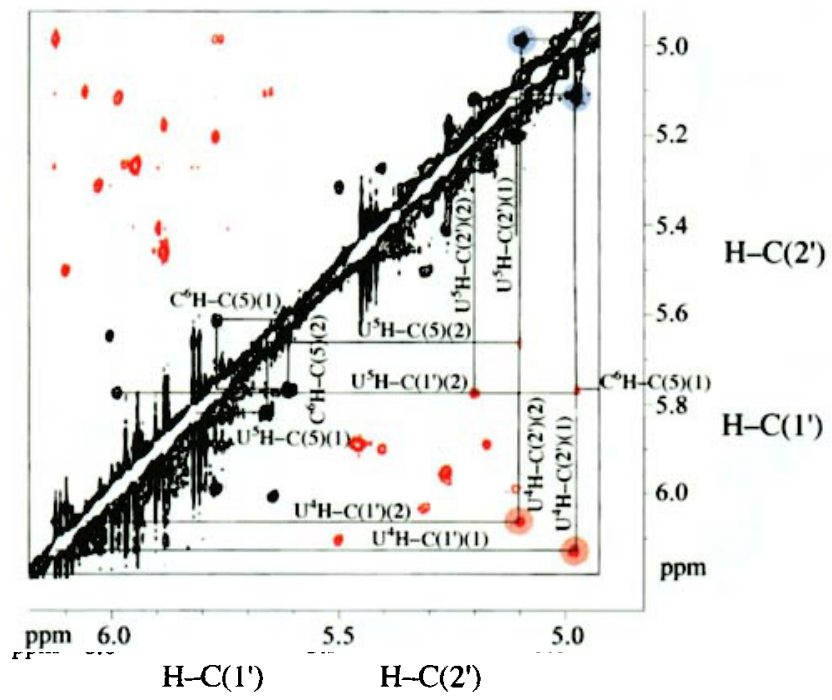

Fig. 8. ROESY Spectrum $(600 \mathrm{MHz})$ of the $2^{\prime}$-fluorinated $5^{\prime}-r\left[C_{f} G C_{f}\left(U_{f} U_{f} C_{f} G\right) G C_{f} G\right]-3^{\prime}$ in the $\left.H-C\left(1^{\prime}\right)\right)$ $H-C\left(2^{\prime}\right)$ region $\left.^{1}\right)$. Peaks which have opposite sign compared to the diagonal are drawn in red. The hairpin region of the molecule is highlighted by assignment. Peaks near the diagonal could be assigned as exchange peaks between the hairpin conformation and the duplex conformation. Circles indicate cross peaks discussed in the text. 
The base-pairing patterns of the fluorinated and the regular RNA oligomer were investigated by $1 \mathrm{D}$ and 2D NOESY experiments in $\mathrm{H}_{2} \mathrm{O}$. For the unmodified RNA 5'-r[CGC(UUCG)GCG]-3' (Fig. 9, a), 5 imino signals can be observed and assigned to characteristic imino signals in the hairpin in Watson-Crick base pairing $\left(\mathrm{G}^{8} \mathrm{H}-\mathrm{C}(1)\right.$, $\left.\mathrm{G}^{2} \mathrm{H}-\mathrm{C}(1)\right)$ and to imino signals of $\mathrm{U}^{4}$ and $\mathrm{G}^{7}$ in the $\mathrm{G} \cdot \mathrm{U}$ base pair of the loop; the 5 th broad signal with a line width of $50 \mathrm{~Hz}$ arises from the $3^{\prime}$-terminal $\mathrm{G}^{10}$ nucleoside.

The two conformations of the fluorinated RNA $5^{\prime}-r\left[C_{f} G_{f}\left(U_{f} U_{f} C_{f} G\right) G C_{f} G\right]-3^{\prime}$ are also apparent from comparison of the imino region of the 1D spectra $(F i g .9, b)$. In the fluorinated oligomer resonances of the hairpin (1) and the duplex (2) conformation are observed. Assignment could be established from the 2D NOESY correlation (vide infra). While the chemical shifts of the imino resonances in the stem of the fluorinated duplex and the fluorinated hairpin are only marginally affected as compared to the unmodified oligomer, the imino resonances involved in the $G \cdot U$ base pair both in the hairpin and in the duplex are shifted by $0.4 \mathrm{ppm}$. Furthermore, their relative peak heights are changed. This suggests different base-pairing geometry and exchange characteristics in the fluorinated oligomer as compared to the unmodified analog. Resolution enhance-

a)

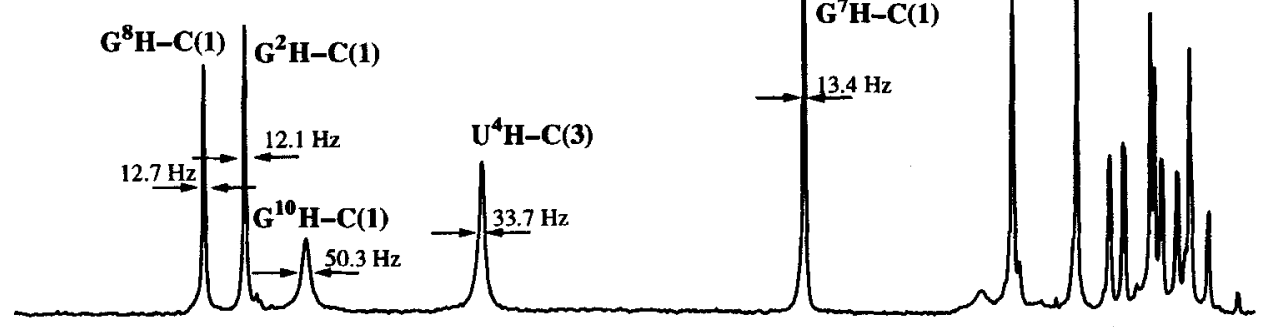

b)

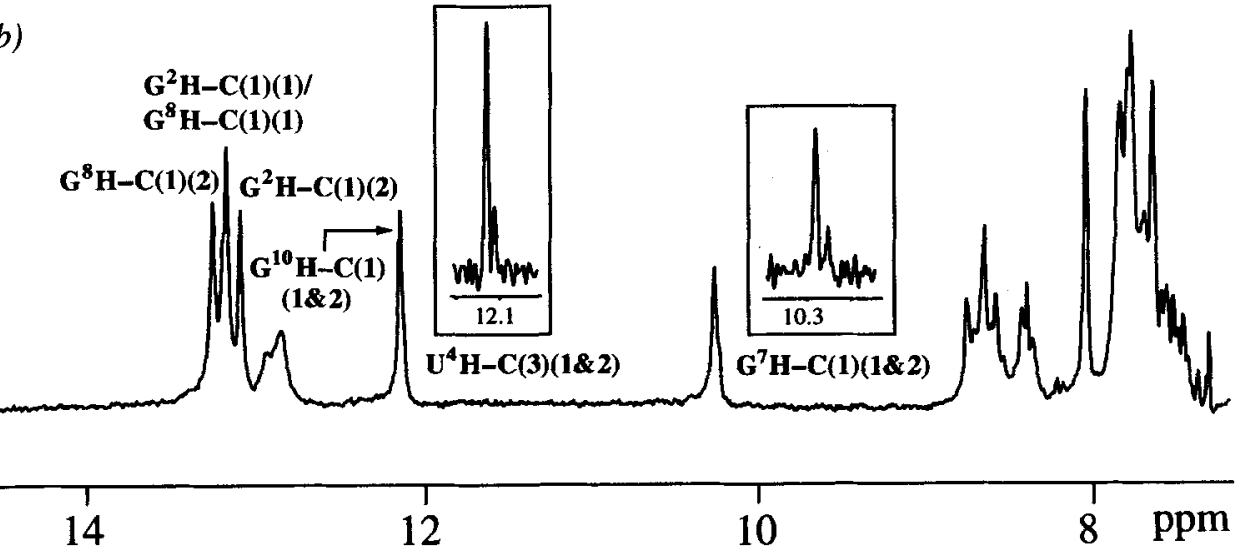

Fig. 9. $1 D^{1} H-H M R$ Spectra $\left(600 \mathrm{MHz}, \mathrm{H}_{2} \mathrm{O}\right)$ of a) the unmodified $5^{\prime}-r\left[C G C(U U C G) G C_{f} G\right]-3^{\prime}$ and b) the $2^{\prime}$-fluorinated $5^{\prime}-r\left[C_{f} G C_{f}\left(U_{f} U_{f} C_{f} G\right) G C_{f} G\right]-3^{\prime}$ in the imino-resonance region $\left.{ }^{1}\right)$ 
ment reveals two peaks for $\mathrm{U}^{4}$ and $\mathrm{G}^{7}$ (inserts in Fig. 9, b) ${ }^{1}$ ), which are assigned to the duplex (downfield signals) and hairpin (upfield signals).

Additionally, characteristic cross peaks for Watson-Crick base pairing are observed for $G^{8}$ and $G^{2}$ in the 2D NOESY correlation of the unmodified RNA oligomer (not shown). While the chemical shifts of $\mathrm{G}^{7}$ and $\mathrm{U}^{4}$ are characteristic for a $\mathrm{G} \cdot \mathrm{U}$ base pair [20] [29], we do not observe an NOE cross peak for this base pair in the unmodified sample, but only a strong exchange peak with the solvent. This is in agreement with findings by Allain and Varani [20] for the UUCG hairpin in the $P 1$ helix of the spliceosome. By contrast, for the $2^{\prime}$-fluorinated RNA oligomer, we observe an NOE cross peak between $\mathrm{U}^{4}$ and $\mathrm{G}^{7}$ in the $2 \mathrm{D}$ NOESY which we assign to the duplex ${ }^{1}$ ), based on the observation that the wobble $G \cdot U$ base pair in a regular A-form helix exhibits such a cross peak (duplex conformation), while it is missing in the distorted $\mathrm{U}^{4} \cdot \mathrm{G}^{7}$ base pair of the hairpin.

The sequential assignment of nonexchanging protons for the fluorinated oligonucleotide can be obtained, in addition to the conventional NOESY approach [30], from a ${ }^{19} \mathrm{~F}$ half-filtered [31] NOESY experiment (Fig. 10). In the conventional NOESY the protons of the fluorinated RNA oligomer have a better resolution than those of the regular oligomer; in the ${ }^{19} \mathrm{~F}$ half-filtered experiment, the spectrum of the fluorinated oligomer is simplified yielding only connectivity information to $\mathrm{H}-\mathrm{C}\left(1^{\prime}\right), \mathrm{H}-\mathrm{C}\left(2^{\prime}\right)$, and $\mathrm{H}-\mathrm{C}\left(3^{\prime}\right)$ of the ${ }^{19} \mathrm{~F}$-labelled pyrimidine residues. A list with the chemical-shift values of all assigned resonances is shown in Table 2. A schematic drawing of the observed sequential NOEs found in the fluorinated hairpin is given in Fig. 11, a, and for the duplex conformation in Fig. 11, b. It turns out that correlations can be observed that are difficult to obtain in the unmodified oligomer due to the severe overlap of the resonance lines in the ribose ring. Especially, the interesting loop region of the hairpin is particularly well defined in

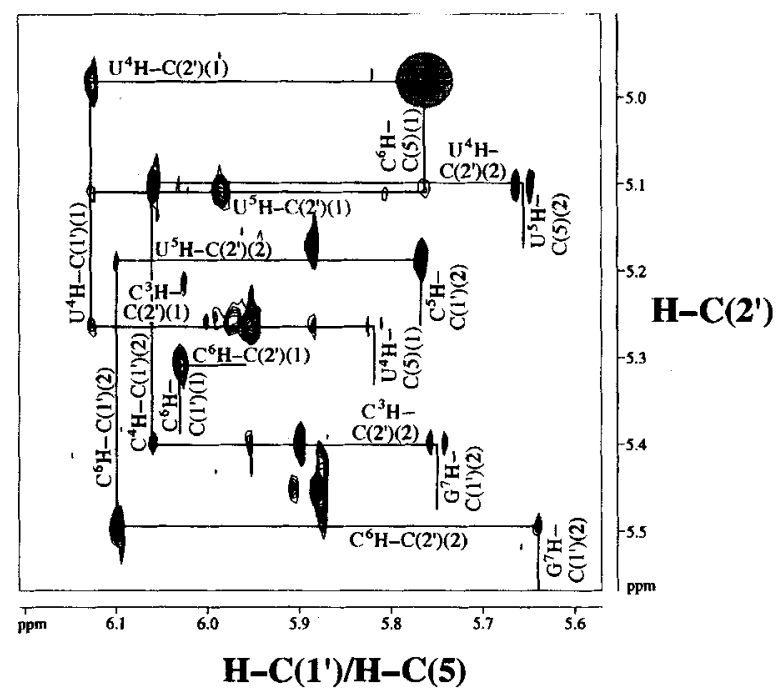

Fig. 10. NOESY Spectrum of the $2^{\prime}$-fluorinated $5^{\prime}-r\left[C_{f} G C_{f}\left(U_{f} U_{f} C_{f} G\right) G C_{f} G\right]-3^{\prime}$ in the $H-C\left(1^{\prime}\right) / H-C\left(2^{\prime}\right)$ region $\left.^{1}\right)$. The $\mathrm{U}^{4} \mathrm{H}-\mathrm{C}\left(2^{\prime}\right)(1) / \mathrm{C}^{6} \mathrm{H}-\mathrm{C}(5)(1)$ cross peak is highlighted in grey. 


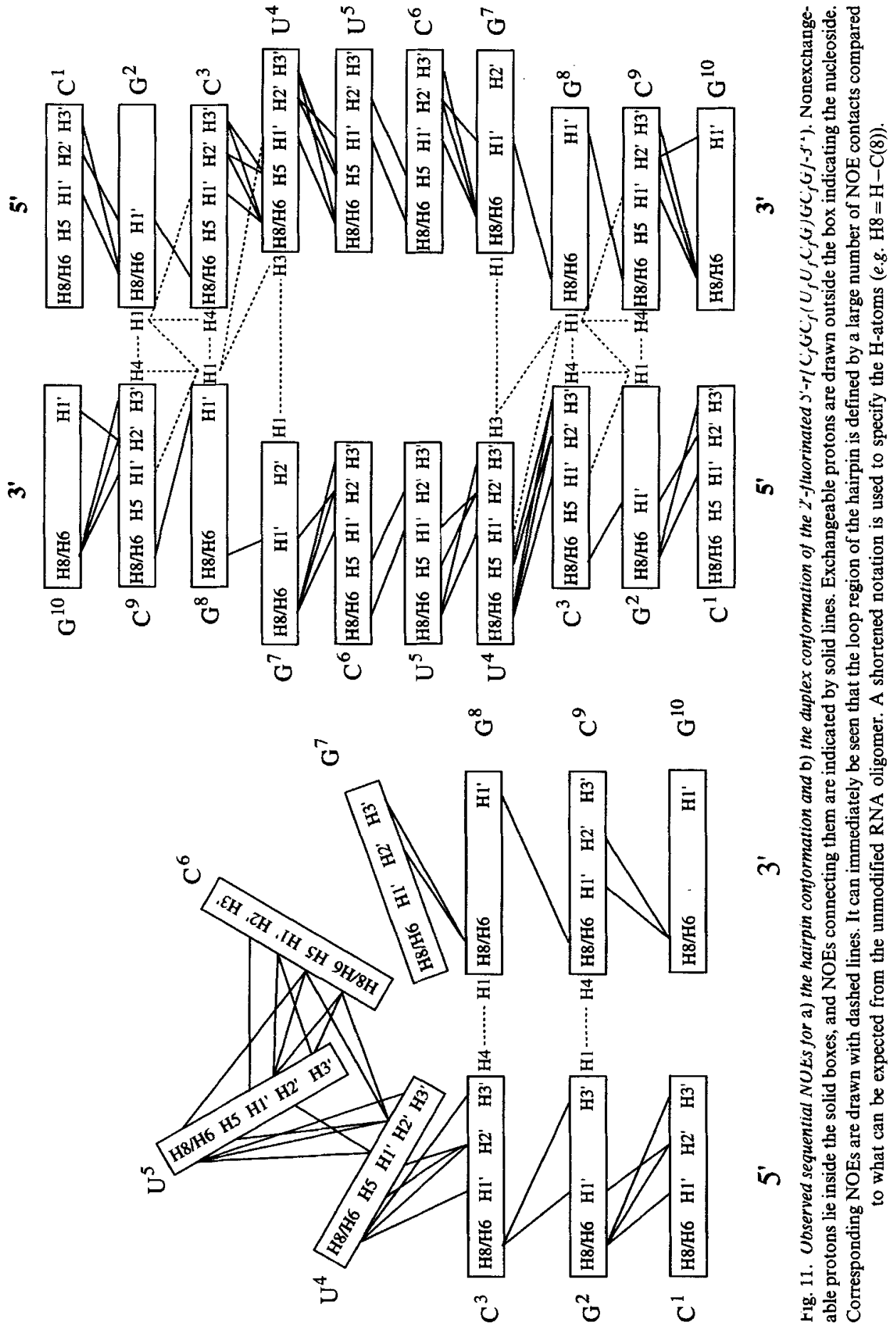


the spectra. The additionally observed cross peaks stem mainly from the $\mathrm{H}-\mathrm{C}\left(2^{\prime}\right)$ and $\mathrm{H}-\mathrm{C}\left(3^{\prime}\right)$ protons that are resolved in the $2^{\prime}$-fluorinated RNA oligomer by employing ${ }^{1} \mathrm{H},{ }^{19} \mathrm{~F}$ correlations in ${ }^{19} \mathrm{~F}$ half-filtered experiments. All observed NOEs are in agreement with the published $P 1$ helix structure [20b].

2.3.2. Conformational Analysis Based on Coupling-Constant Information from ${ }^{19} \mathrm{~F}^{1} \mathrm{H}$-HSQC-E.COSY Experiments. The sugar puckering in oligonucleotides can be determined from analysis of homonuclear coupling constants. In unlabelled oligoribonucleotides, relative intensities of moderately well resolved $\mathrm{H}-\mathrm{C}\left(1^{\prime}\right), \mathrm{H}-\mathrm{C}\left(2^{\prime}\right)$ cross peaks in DQF-COSY experiments can be used to qualitatively determine the sugar-puckering mode. Cross peaks are expected to be strong/weak for $\mathrm{C}\left(2^{\prime}\right) / \mathrm{C}\left(3^{\prime}\right)$-endo conformations [32]. In ${ }^{13} \mathrm{C}$-labelled oligonucleotides, ${ }^{3} J\left(\mathrm{H}-\mathrm{C}\left(1^{\prime}\right), \mathrm{H}-\mathrm{C}\left(2^{\prime}\right)\right)$ coupling constants can be determined in HCCH-E.COSY [33] and ${ }^{3} J\left(\mathrm{H}-\mathrm{C}\left(1^{\prime}\right), \mathrm{H}-\mathrm{C}\left(2^{\prime}\right)\right),{ }^{3} J\left(\mathrm{H}-\mathrm{C}\left(2^{\prime}\right), \mathrm{H}-\mathrm{C}\left(3^{\prime}\right)\right)$, and ${ }^{3} J\left(\mathrm{H}-\mathrm{C}\left(3^{\prime}\right), \mathrm{H}-\mathrm{C}\left(4^{\prime}\right)\right)$ in the forward-directed HCC-TOCSY-CCH-E.COSY [34] experiments.

Three-bond ${ }^{3} J\left(\mathrm{H}-\mathrm{C}\left(1^{\prime}\right), \mathrm{H}-\mathrm{C}\left(2^{\prime}\right)\right)$ and ${ }^{3} J\left(\mathrm{H}-\mathrm{C}\left(2^{\prime}\right), \mathrm{H}-\mathrm{C}\left(3^{\prime}\right)\right)$ coupling constants were determined for the fluorinated $5^{\prime}-\mathrm{r}\left[\mathrm{C}_{\mathrm{f}} \mathrm{GC}_{\mathrm{f}}\left(\mathrm{U}_{\mathrm{f}} \mathrm{U}_{\mathrm{f}} \mathrm{C}_{\mathrm{f}} \mathrm{G}\right) \mathrm{GC}_{\mathrm{f}} \mathrm{G}\right]-3^{\prime}$ using an E.COSYtype experiment with spin-topology filtering. The experiment relies on the observation that the ${ }^{2} J\left(\mathrm{H}-\mathrm{C}\left(2^{\prime}\right), \mathrm{F}-\mathrm{C}\left(2^{\prime}\right)\right)$ coupling constant does not depend on the sugar conformation and is approximately four times larger than the ${ }^{3} J\left(\mathrm{H}-\mathrm{C}\left(1^{\prime}\right), \mathrm{F}-\mathrm{C}\left(2^{\prime}\right)\right)$ and ${ }^{3} J\left(\mathrm{H}-\mathrm{C}\left(3^{\prime}\right), \mathrm{F}-\mathrm{C}\left(2^{\prime}\right)\right)$ coupling constants. Therefore, the $\mathrm{H}-\mathrm{C}\left(2^{\prime}\right), \mathrm{F}-\mathrm{C}\left(2^{\prime}\right)$ pair resembles very much the $\mathrm{H},{ }^{15} \mathrm{~N}$ pair in a labelled protein or the $\mathrm{H},{ }^{13} \mathrm{C}$ pair in a molecule with natural abundance of $\mathrm{C}$-atoms. Thus, a whole class of editing and filtering experiment and accessories in homonuclear correlation experiments are possible that rely on the large difference in the size of ${ }^{2} J\left(\mathrm{H}-\mathrm{C}\left(2^{\prime}\right), \mathrm{F}-\mathrm{C}\left(2^{\prime}\right)\right)$ as compared to all other $J(\mathrm{H}, \mathrm{F})$ or $J(\mathrm{H}, \mathrm{H})$ coupling constants.

The pulse sequence for the determination of ${ }^{3} J(\mathrm{H}, \mathrm{H})$ coupling constants is shown in $F$ ig. 12, $a$. The experiment is essentially a gradient-enhanced ${ }^{19} \mathrm{~F},{ }^{1} \mathrm{H}-\mathrm{HSQC}$ for correlations via the ${ }^{3} J\left(\mathrm{H}-\mathrm{C}\left(\mathbf{1}^{\prime}\right), \mathrm{F}-\mathrm{C}\left(2^{\prime}\right)\right)$ and ${ }^{3} J\left(\mathrm{H}-\mathrm{C}\left(3^{\prime}\right), \mathrm{F}-\mathrm{C}\left(2^{\prime}\right)\right)$ coupling constants, employing $\mathrm{COS}$ (coherence order selective) transfer [35]. The COS transfer element also ensures that the passive $\mathrm{H}-\mathrm{C}\left(2^{\prime}\right)$ is not touched between $t_{1}$ and the detection period. This is achieved by tuning the delay $\Delta^{\prime}$ for the large ${ }^{2} J\left(\mathrm{~F}-\mathrm{C}\left(2^{\prime}\right), \mathrm{H}-\mathrm{C}\left(2^{\prime}\right)\right)$ coupling constant $\left(2 \Delta^{\prime}=\right.$ $\left.\left[{ }^{2} J\left(\mathrm{~F}-\mathrm{C}\left(2^{\prime}\right), \mathrm{H}-\mathrm{C}\left(2^{\prime}\right)\right)\right]^{-1}\right)$ resulting in an E.COSY-type pattern much the same as in the HNCA-E.COSY experiment [36]. Thus, during the two $2 \Delta^{\prime}$ segments, neglecting homonuclear couplings, which are small compared to the heteronuclear coupling, and chemical shift, $\mathrm{H}-\mathrm{C}\left(2^{\prime}\right)$ behaves as an isolated spin. It can easily be seen that the pulse sandwich $90_{x} 180_{x} 90_{y} 180_{x} 90_{x} 180_{x}$ leaves $z$-magnetization unrotated yielding the desired behavior for the passive spin in an E.COSY experiment. The antiphase coherence, e.g. $2\left(F 2^{\prime}\right)^{ \pm} H 1^{\prime}$, is transferred to detectable coherence $\left(H i^{\prime}\right){ }^{-}$with a transfer efficiency of $\sin \left(\pi \cdot{ }^{3} J\left(\mathrm{H}-\mathrm{C}\left(1^{\prime}\right), \mathrm{F}-\mathrm{C}\left(2^{\prime}\right)\right) \cdot 2 \Delta^{\prime}\right)+\sin \left(\pi \cdot{ }^{3} J\left(\mathrm{H}-\mathrm{C}\left(1^{\prime}\right), \mathrm{F}-\mathrm{C}\left(2^{\prime}\right)\right)\right.$ $\left.2 \Delta^{\prime}\right) \cdot \cos \left(\pi \cdot{ }^{3} J\left(\mathrm{H}-\mathrm{C}\left(3^{\prime}\right), \mathrm{F}-\mathrm{C}\left(2^{\prime}\right)\right) \cdot 2 \Delta^{\prime}\right)[37]$. The evolution of homonuclear couplings has been neglected so far. Evolution of homonuclear coupling involves the small ${ }^{3} J\left(\mathrm{H}-\mathrm{C}\left(1^{\prime}\right), \mathrm{H}-\mathrm{C}\left(2^{\prime}\right)\right)$ which is not larger than $7 \mathrm{~Hz}$ and, therefore, 7.5 times smaller than ${ }^{2} J\left(\mathrm{H}-\mathrm{C}\left(2^{\prime}\right), \mathrm{F}-\mathrm{C}\left(2^{\prime}\right)\right)$. This leads to intensity errors $<10 \%$. The ${ }^{3} J\left(\mathrm{H}-\mathrm{C}\left(2^{\prime}\right), \mathrm{H}-\mathrm{C}\left(3^{\prime}\right)\right)$ coupling constant is smaller than $5 \mathrm{~Hz}$ for both the $\mathrm{C}\left(2^{\prime}\right)$-endo and $\mathrm{C}\left(3^{\prime}\right)$-endo conformation leading to additional intensity erros of less than $4 \%$.

The schematic cross-peak pattern in the E.COSY-type experiment according to Fig. 12, $a$ (see above) is shown in Fig. 12, b: For the $\mathrm{F}-\mathrm{C}\left(2^{\prime}\right), \mathrm{H}-\mathrm{C}\left(1^{\prime}\right)$ cross peak shown on the left, the two sub-multiplet patterns are separated by the displacement vector $\boldsymbol{J}_{\mathbf{F}}$ with the components ${ }^{2} J\left(\mathrm{H}-\mathrm{C}\left(2^{\prime}\right), \mathrm{F}-\mathrm{C}\left(2^{\prime}\right)\right)$ as associated coupling in $\omega_{1}$ and ${ }^{3} J\left(\mathrm{H}-\mathrm{C}\left(1^{\prime}\right), \mathrm{H}-\mathrm{C}\left(2^{\prime}\right)\right)$ as coupling of interest in $\omega_{2}$. In the $m$ observed in the $\mathrm{F}-\mathrm{C}\left(2^{\prime}\right), \mathrm{H}-\mathrm{C}\left(3^{\prime}\right)$ cross peak shown on the right, the ${ }^{3} J\left(\mathrm{H}-\mathrm{C}\left(2^{\prime}\right), \mathrm{H}-\mathrm{C}\left(3^{\prime}\right)\right)$ coupling 


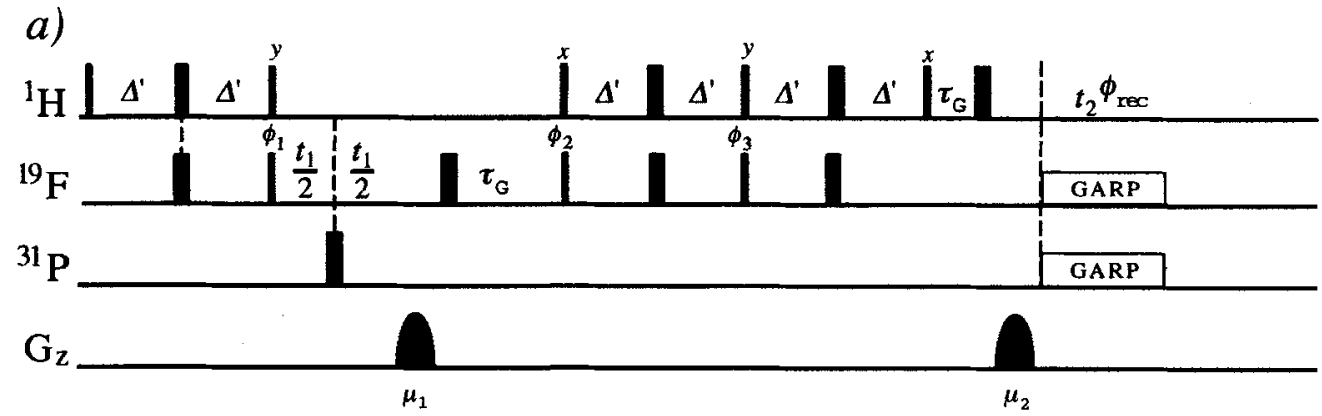

b)

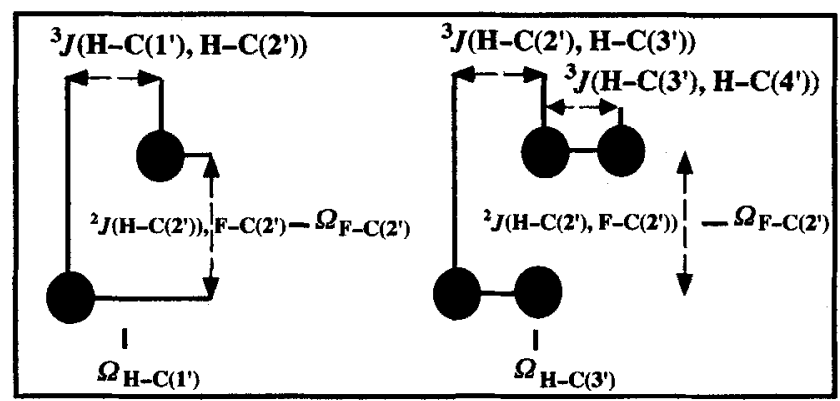

c)

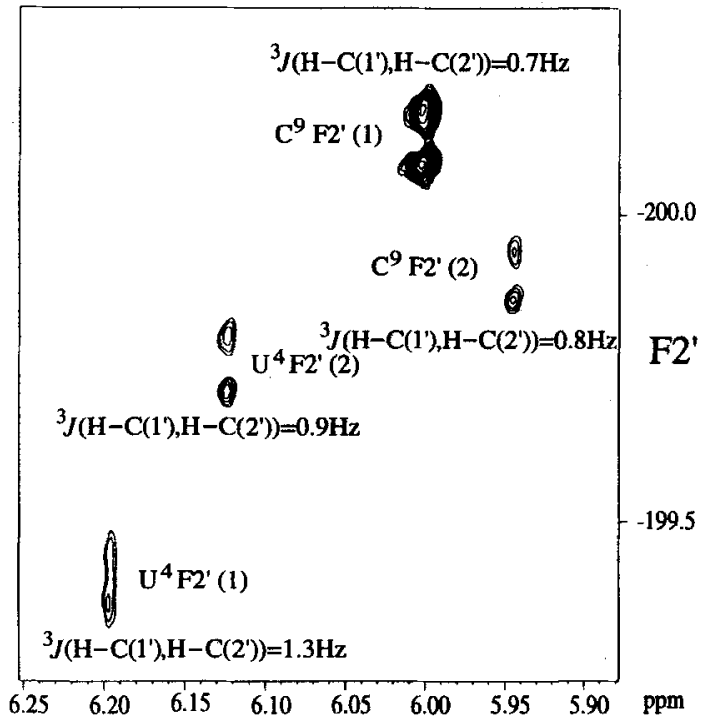

$\mathrm{H}-\mathrm{C}\left(3^{\prime}\right)$

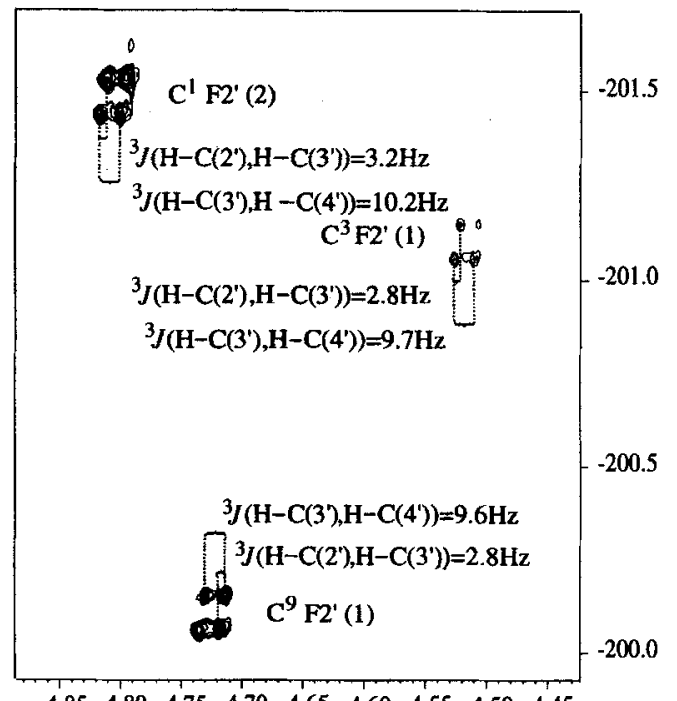

Fig. 12. a) Pulse sequence for the ${ }^{19} F^{1}{ }^{1} H$-HSQC-E.COSY experiment. b) Schematic drawing of the expected cross-peak pattern (the $\mathrm{H}-\mathrm{C}\left(1^{\prime}\right) / \mathrm{F}-\mathrm{C}\left(2^{\prime}\right)$ cross peak is splitted by ${ }^{3} J\left(\mathrm{H}-\mathrm{C}\left(1^{\prime}\right), \mathrm{H}-\mathrm{C}\left(2^{\prime}\right)\right)$ in $\omega_{2}$ and ${ }^{2} J\left(\mathrm{H}-\mathrm{C}\left(2^{\prime}\right)\right.$, $\left.\mathrm{F}-\mathrm{C}\left(2^{\prime}\right)\right)$ in $\omega_{1}$; the $\mathrm{F}$-atom is not affected during the back transfer of the magnetization, resulting in the indicated E.COSY splitting; the $\mathrm{H}-\mathrm{C}\left(3^{\prime}\right) / \mathrm{F}-\mathrm{C}\left(2^{\prime}\right)$ cross peak is, in addition to splitting by ${ }^{3} J\left(\mathrm{H}-\mathrm{C}\left(2^{\prime}\right), \mathrm{H}-\mathrm{C}\left(3^{\prime}\right)\right)$ and ${ }^{2} J\left(\mathrm{H}-\mathrm{C}\left(2^{\prime}\right), \mathrm{F}-\mathrm{C}\left(2^{\prime}\right)\right.$, split by the passive ${ }^{3} J\left(\mathrm{H}-\mathrm{C}\left(3^{\prime}\right), \mathrm{H}-\mathrm{C}\left(4^{\prime}\right)\right)$ in $\left.\omega_{2}\right)$. c) Experimentally obtained spectrum $\left.\left(\mathrm{F} 2^{\prime}=\mathrm{F}-\mathrm{C}\left(2^{\prime}\right)\right)^{1}\right)$ 
constant can be determined from the E.COSY-type displacement of the two sub-multiplet. Each sub-multiplet itself is further split due to the homonuclear ${ }^{3} J\left(\mathrm{H}-\mathrm{C}\left(3^{\prime}\right), \mathrm{H}-\mathrm{C}\left(4^{\prime}\right)\right)$ coupling constant, which is, at least for the $\mathrm{C}\left(3^{\prime}\right)$-endo conformation, large enough to be read off by direct inspection, as can be seen in the spectrum shown in Fig. 12, c. Table 3 contains the extracted coupling constants for the duplex and the hairpin conformation. All six fluorinated nucleosides in the duplex and the residues in the stem region of the hairpin have small ${ }^{3} J\left(\mathrm{H}-\mathrm{C}\left(1^{\prime}\right), \mathrm{H}-\mathrm{C}\left(2^{\prime}\right)\right)$ coupling constants indicating a pure $\mathrm{C}\left(3^{\prime}\right)$-endo conformation in the duplex. The coupling constants for the loop residues $\mathrm{U}_{\mathrm{f}}^{5}$ and $\mathrm{C}_{\mathrm{f}}^{6}$ in the hairpin conformation, ${ }^{3} J\left(\mathrm{H}-\mathrm{C}\left(1^{\prime}\right), \mathrm{H}-\mathrm{C}\left(2^{\prime}\right)\right)=4.0 \mathrm{~Hz}$ for $\mathrm{U}_{\mathrm{f}}^{5}$ and ${ }^{3} J\left(\mathrm{H}-\mathrm{C}\left(1^{\prime}\right)\right.$, $\left.\mathrm{H}-\mathrm{C}\left(2^{\prime}\right)\right)=3.3 \mathrm{~Hz}$ for $\mathrm{C}_{\mathrm{f}}^{6}$, are in agreement with a ca. 50:50 equilibrium between $\mathrm{C}\left(2^{\prime}\right)$-endo and $\mathrm{C}\left(3^{\prime}\right)$-endo for $\mathrm{U}_{\mathrm{f}}^{5}$ and ca. 40:60 equilibrium for $C_{\mathrm{f}}^{6}$ (assuming an 8-Hz coupling constant for pure $\mathrm{C}\left(2^{\prime}\right)$-endo and $0 \mathrm{~Hz}$ for pure $\mathrm{C}\left(3^{\prime}\right)$-endo) [38]. The intermediate size of the coupling constants hinting at the conformational heterogeneity is also observed in unmodified oligomers [20a]. Therefore, we have every reason to believe that the conformational processes observed for the fluorinated hairpin are also present for the unmodified one. However, the time scale of interconversion might be different.

3. Discussion. - 3.1. Comparison of the Quality of NMR Data with and without ${ }^{19} \mathrm{~F}$-Labelling. The substitution of the $\mathrm{OH}$ by ${ }^{19} \mathrm{~F}$ at the 2 -position in oligoribonucleotides improves the quality of structures by increasing the number of available restraints for a structure calculation. The number of NOEs can be raised by increasing the resolution in the ${ }^{1} \mathrm{H}$ and ${ }^{13} \mathrm{C}$ dimension and allowing to apply isotope half-filtered experiments with a high signal-to-noise ratio. Furthermore, vicinal ${ }^{3} J(\mathrm{H}, \mathrm{H})$ coupling constants, especially ${ }^{3} J\left(\mathrm{H}-\mathrm{C}\left(1^{\prime}\right), \mathrm{H}-\mathrm{C}\left(2^{\prime}\right)\right)$ and ${ }^{3} J\left(\mathrm{H}-\mathrm{C}\left(2^{\prime}\right), \mathrm{H}-\mathrm{C}\left(3^{\prime}\right)\right)$, and ${ }^{3} J(\mathrm{H}, \mathrm{F})$ coupling constants, defining the conformation and dynamics of the sugar moieties can be determined. We did not observe any correlation in a heteronuclear F,H-NOESY experiment other than between $\mathrm{F}-\mathrm{C}\left(2^{\prime}\right)$ and the geminal $\mathrm{H}-\mathrm{C}\left(2^{\prime}\right)$. This is due to the fact that the heteronuclear NOE vanishes at a spectrometer frequency of $600 \mathrm{MHz}$ for molecules tumbling with a correlation time of $c a .2 \mathrm{~ns}$ [39].

${ }^{1} \mathrm{H},{ }^{19} \mathrm{~F}$ Correlation experiments are among the most sensitive experiments due to the large scalar coupling constants involved. The ${ }^{19} \mathrm{~F}$-chemical shifts reveal insight about the sugar conformation. This makes F-labelling even for large molecules an attractive and economic tool for site-specific labelling of RNA molecules. We find in this study, however, that incorporation of an $\mathrm{F}$-atom at the $2^{\prime}$-position may change the energetics of the conformations as compared to unmodified RNA oligomers. At the same time, the structural changes were below the limit of NMR structure determination.

3.2. Interpretation of the Melting Curves. The melting curves of the unmodified hairpin shows a melting point at $72.7^{\circ}$. This result is in agreement with previous studies which showed that only three $\mathrm{G} \cdot \mathrm{C}$ base pairs are sufficient to stabilize the hairpin conformation. The transition is highly cooperative as observed for hairpins with longer stems.

The melting curve of the fluorinated oligoribonucleotide shows a mid point of transition at $74.7^{\circ}$. In contrast to the unmodified sample, the $2^{\prime}$-fluorinated oligonucleotide shows a much broader melting transition, indicating a smaller change of entropy upon melting between hairpin and molten strand (Table 1). This is in agreement with the notion of a larger conformational rigidity of the fluorinated oligonucleotides $v s$. unmod- 
ified oligomer. We interpret this finding in terms of a high amount of stacking interaction still present in the molten strand.

3.3. Discussion of the Duplex Structure. The duplex structure of the fluorinated oligonucleotide is formed by one A-form helix that contains a fully stacked CU - UC mismatch pair. We do not observe exchangeable protons for this mismatch pair. This is expected from work in DNA where only at $\mathrm{pH} 5$ cytidines become protonated and form $\mathrm{C}^{+} \cdot \mathrm{U}$ base pairs [26] [29]. In contrast to the fluorinated hairpin, no strong intranucleotide $\mathrm{H}-\mathrm{C}(8), \mathrm{H}-\mathrm{C}\left(1^{\prime}\right)$ cross peak could be observed, indicating an anti orientation of the base $\mathrm{G}^{7}$ in the duplex conformation.

3.4. Discussion of the Hairpin Structure. All the structural evidence, NOEs, coupling constants, and even chemical shifts for the fluorinated RNA hairpin are in agreement with the published data for the unmodified hairpin. We observe a yet unknown exchange process on a submillisecond time scale that affects the chemical shift of the two ${ }^{19} \mathrm{~F}$ resonances of $\mathrm{U}_{\mathrm{f}}^{5}$ and $\mathrm{C}_{\mathrm{f}}^{6}$. We suggest that this chemical exchange is brought about by the pseudorotation jump of the two sugar moieties of $\mathrm{U}_{\mathrm{f}}^{5}$ and $\mathrm{C}_{\mathrm{f}}^{6}$ which is corroborated by analysis of the ${ }^{3} J(\mathrm{H}, \mathrm{H})$ coupling constants. DFT Calculations suggest chemical shift differences of $c a .27 \mathrm{ppm}$ between a $\mathrm{C}\left(2^{\prime}\right)$-endo and $\mathrm{C}\left(3^{\prime}\right)$-endo ribose conformation [40]. The sign of the shift is an agreement with the high-field shift of the two ${ }^{19} \mathrm{~F}$ resonances of $\mathrm{U}_{\mathrm{f}}^{5}$ and $\mathrm{C}_{\mathrm{f}}^{6}$ compared to the bulk of ${ }^{19} \mathrm{~F}$ resonances; however, the size of the effect should be a factor of 2 smaller.

The existence of the duplex structure in the fluorinated but not in the unmodified RNA oligomer shows that interactions that specifically stabilize the hairpin $v s$. the duplex are removed upon fluorination. From the structural features derived, we tentatively propose the following interactions:

a) $\mathrm{OH}$ Groups in RNA are known to play an important role for RNA folding [41]. There is also experimental evidence that $2^{\prime}-\mathrm{OH}$ groups are protected from exchange with the solvent and, therefore, must be involved in $\mathrm{H}$-bridges that stabilize hairpin structures as determined for the $P 1$ Intron loop (e.g., $\mathrm{U}^{4} \mathrm{C}\left(2^{\prime}\right)-\mathrm{OH}$ to $\left.\mathrm{G}^{7} \mathrm{~N}(1)-\mathrm{H}\right)$ [20b] [42]. Substitution of the $\mathrm{OH}$ groups by F-atoms will weaken the H-bonding network, although a F-atom can be a $\mathrm{H}$-bridge acceptor in certain cases [43]. On the other hand, the analogous DNA oligomers, which are known to form hairpins, have a considerably decreased melting point [44]. There is no evidence for an equilibrium between two DNA oligomer conformations, however. Introduction of F-atoms seems to have mainly an influence on the thermodynamics of the interconversion between duplex and hairpin, but does not influence the absolute value of the melting point which is still unusually high in the fluorinated oligonucleotide.

$b$ ) The sugar pucker of the $\mathrm{U}_{\mathrm{f}}^{5}$ and $\mathrm{C}_{\mathrm{f}}^{6}$ residues of the fluorinated oligonucleotide is in equilibrium between $\mathrm{C}\left(2^{\prime}\right)$-endo and $\mathrm{C}\left(3^{\prime}\right)$-endo as derived from the analysis of coupling constants. The $\mathrm{C}\left(2^{\prime}\right)$-endo conformation is destabilized in the fluorinated ribonucleotide as compared to the unmodified ribonucleotide. The molecule in the duplex conformation does not need to resort to the $\mathrm{C}\left(2^{\prime}\right)$-endo conformation. This could be an explanation for the observed equilibrium between hairpin and duplex which is not seen in the unmodified oligomer, and for the induced destabilization of the fluorinated hairpin. This proposition is substantiated by the DFT calculations of the ${ }^{19} \mathrm{~F}$-chemical shifts showing a difference of $c a .20 \mathrm{ppm}$ between the $\mathrm{C}\left(2^{\prime}\right)$-endo and $\mathrm{C}\left(3^{\prime}\right)$-endo conformation. 
This finding is also in agreement with empirical studies on ${ }^{19} \mathrm{~F}$-chemical shifts from $\alpha$ and $\beta$-D-anomers of 2-deoxy-2-fluoro-D-mannosides [19].

We plan to determine the relative importance of these interactions by synthesis of selectively fluorinated RNA, the thermodynamical analysis, and spectroscopy. The current study revealed that $2^{\prime}$-fluorinated RNA is an appropriate model system to study the influence of local changes of the constitution on the thermodynamics of interconversions between different conformations.

4. Conclusion. - We have shown on the example of a UUCG tetraloop that, due to the very good dispersion of the ${ }^{19} \mathrm{~F}-\mathrm{NMR}$ resonances, the resolution of the $\mathrm{H}-\mathrm{C}\left(2^{\prime}\right)$ resonances, as well as the uniquely large ${ }^{2} J\left(\mathrm{H}-\mathrm{C}\left(2^{\prime}\right), \mathrm{F}-\mathrm{C}\left(2^{\prime}\right)\right)$ coupling constant, the NMR spectroscopy of fluorinated oligonucleotides yields additional information that cannot be obtained by NMR of regular RNA oligomers. We have also detected a previously unknown process on a submillisecond time scale for the fluorinated hairpin which is probably due to slow sugar pseudorotation of the crown residues $U_{f}^{5}$ and $C_{f}^{6}$ in the hairpin loop. At the same time, the molecule shows an interconversion between two conformers, hairpin and duplex, with a rate of $0.3 \mathrm{~Hz}$. The change of thermodynamics of the RNA-oligomer structures is also monitored in the different melting behaviour between the fluorinated and unmodified sample.

\section{Experimental Part}

General. 2'-Deoxy-2'-fluorouridine (2) was prepared from 2,2'-anhydro-1-( $\beta$-D-arabinofuranosyl)uracil (1) (Aldrich) by a reported procedure [11]. Anh. pyridine and anh. $\mathrm{CH}_{2} \mathrm{Cl}_{2}$ were obtained from Fluka and used without further purification. Flash column chromatography (FC): silica gel $60(40-63 \mu \mathrm{m})$ from Merck; for acid-sensitive compounds, the dry-packed column was pre-equilibrated with a $\mathrm{Et}_{3} \mathrm{~N}$-containing solvent until detection of the base in the eluent, then the column was run dry and equilibrated with the appropriate solvent system (without base) prion to FC. TLC: silica gel $60 F_{254}$ plates (Macherey-Nagel), visualization by quenching of fluorescence followed by charring after treatment with cerium molybdophosphate; in the case of the phosphoramidites, the plates were pretreated with $\mathrm{AcOEt} / \mathrm{Et}_{3} \mathrm{~N} 9: 1$ and dried before spotting the compounds.

$2^{\prime}$-Deoxy-5'-O- $\left(4,4^{\prime}\right.$-dimethoxytrityl $)$-2'-fluorouridine. $2^{\prime}$-Deoxy-2'-fluorouridine $(2 ; 410 \mathrm{mg}, 1.66 \mathrm{mmol})$ was co-evaporated with anh. pyridine $(2 \times 4 \mathrm{ml})$ and dissolved in anh. pyridine $(6 \mathrm{ml})$ under $\mathrm{Ar}$. Then, $\mathrm{Et}_{3} \mathrm{~N}(348 \mu \mathrm{l}$, $2.50 \mathrm{mmol})$ and $(\mathrm{MeO})_{2} \mathrm{Tr}-\mathrm{Cl}(846 \mathrm{mg}, 2.50 \mathrm{mmol})$ were added. After $1.5 \mathrm{~h}$ of stirring, $\mathrm{MeOH}(2 \mathrm{ml})$ was added, and the mixture was evaporated and co-evaporated with toluene $(2 \times 5 \mathrm{ml})$. The residue was dissolved in $\mathrm{CHCl}_{3}$ $(30 \mathrm{ml})$, the soln. washed with sat. $\mathrm{NaHCO}_{3}$ soln., dried $\left(\mathrm{Na}_{2} \mathrm{SO}_{4}\right)$, and evaporated, and the resulting yellow syrup purified by $\mathrm{FC}\left(200 \mathrm{~g}\right.$ of $\mathrm{SiO}_{2}$, pre-equilibration with $\mathrm{CHCl}_{3} / \mathrm{MeOH} / \mathrm{Et}_{3} \mathrm{~N}$ 95:5:5, then $\mathrm{CHCl}_{3} / \mathrm{MeOH}$ 100:0 $\rightarrow 95: 5): 885 \mathrm{mg}(97 \%)$ of white solid after lyophilization from benzene. $R_{\mathrm{f}} \mathrm{CHCl}_{3} / \mathrm{MeOH}(95: 5)$ 0.15. ${ }^{1} \mathrm{H}$ - and ${ }^{13} \mathrm{C}-\mathrm{NMR}$ : in agreement with those published [11].

$2^{\prime}$-Deoxy-5'-O-(4,4'dimethoxytrityl)-2'-fluorouridine $3^{\prime}-(2$-Cyanoethyl Diisopropylphosphoramidite) (3). $2^{\prime}$-Deoxy-5'-O-(4,4'-dimethoxytrityl)-2'-fluoro-uridine $(885 \mathrm{mg}, 1.61 \mathrm{mmol})$, having been lyophilized from benzene, was dried overnight in vacuum. After addition of (i-Pr) $)_{2} \mathrm{EtN}(829 \mu \mathrm{l}, 4.84 \mathrm{mmol})$ and anh. $\mathrm{CH}_{2} \mathrm{Cl}_{2}(5 \mathrm{ml})$, the soln. was cooled to $0^{\circ}$ and $\mathrm{PCl}\left[\mathrm{N}(\mathrm{i}-\mathrm{Pr})_{2}\right]\left(\mathrm{OCH}_{2} \mathrm{CH}_{2} \mathrm{CN}\right)(540 \mu \mathrm{l}, 2.42 \mathrm{mmol})$ was added under Ar. The mixture was stirred for $5 \mathrm{~min}$ at $0^{\circ}$ and for $2 \mathrm{~h}$ at r.t. $\mathrm{CH}_{2} \mathrm{Cl}_{2}(30 \mathrm{ml})$ was added and the org. phase washed with sat. $\mathrm{NaHCO}_{3}$ soln., dried $\left(\mathrm{Na}_{2} \mathrm{SO}_{4}\right)$, and, after addition of a few drops of $\mathrm{Et}_{3} \mathrm{~N}$, filtered and evaporated. $\mathrm{FC}(80 \mathrm{~g}$ of $\mathrm{SiO}_{2}$, pre-equilibration with toluene/AcOEt/Et ${ }_{3} \mathrm{~N}$ 1:5:0.6, then toluene/AcOEt $\left.1: 5\right)$ gave $3(1.01 \mathrm{~g}, 84 \%)$ as a white solid after lyophilization from benzene. $\boldsymbol{R}_{\mathrm{f}}$ (toluene/AcOEt 1:5) $0.48,0.55 .{ }^{31} \mathrm{P}-\mathrm{NMR}$ in agreement with those published [11].

$2^{\prime}$-Deoxy-2'-fluorocytidine (5). Compound $2(787 \mathrm{mg}, 3.20 \mathrm{mmol})$ was stirred with pyridine $(8 \mathrm{ml})$ and $\mathrm{Ac}_{2} \mathrm{O}$ $(1.21 \mathrm{ml}, 12.8 \mathrm{mmol})$ for $2 \mathrm{~h}$ at r.t., evaporated, and co-evaporated with toluene $(2 \times 5 \mathrm{ml})$. FC $\left(100 \mathrm{~g} \mathrm{of} \mathrm{SiO}_{2}\right.$, $\left.\mathrm{CHCl}_{3} / \mathrm{MeOH} 15: 1\right)$ gave 3',5'-di-O-acetyl-2'-deoxy-2'-fluorouridine (971 $\mathrm{mg}, 92 \%$ ) as a white solid. Thereof, $944 \mathrm{mg}$ ( $2.86 \mathrm{mmol})$ were added to a suspension of 3-nitro-1 $\mathrm{H}-1,2,4$-triazole $(815 \mathrm{mg}, 7.15 \mathrm{mmol}), \mathrm{MeCN}(20 \mathrm{ml})$, 
(PhO) ${ }_{2} \mathrm{POCl}(1.48 \mathrm{ml}, 7.15 \mathrm{mmol})$, and $\mathrm{Et}_{3} \mathrm{~N}(2 \mathrm{ml}, 14.3 \mathrm{mmol})$ [24]. The mixture was stirred for $1.5 \mathrm{~h}$ at r.t. After addition of $\mathrm{H}_{2} \mathrm{O}(2 \mathrm{ml})$, the mixture was evaporated, the remainder dissolved in AcOEt $(50 \mathrm{ml})$, and the soln. washed with sat. $\mathrm{NaHCO}_{3}$ soln. $(3 \times 50 \mathrm{ml})$ and $\mathrm{H}_{2} \mathrm{O}(2 \times 50 \mathrm{ml})$, dried $\left(\mathrm{Na}_{2} \mathrm{SO}_{4}\right.$ with addition of some activated charcoal) and evaporated to give $4(1.24 \mathrm{~g}$, quant.) as a light brown foam which was essentially free of by-products according to TLC $\left(R_{\mathrm{f}}\left(\mathrm{CHCl}_{3} / \mathrm{MeOH} 95: 5\right) 0.38\right)$. At r.t., $4(1.19 \mathrm{~g}, 2.80 \mathrm{mmol})$ was treated with dioxane $(14 \mathrm{ml})$ and $32 \%$ aq. $\mathrm{NH}_{3}$ soln. $(2 \mathrm{ml})$ for $20 \mathrm{~min}$, evaporated and co-evaporated with $\mathrm{MeOH}(10 \mathrm{ml})$. Anh. $\mathrm{MeOH}$ $(20 \mathrm{ml})$ and $\mathrm{EtNMe}_{2}(4 \mathrm{ml})$ were added, and the mixture was stirred at $50^{\circ}$ until $\mathrm{TLC}\left(\mathrm{MeCN} / \mathrm{H}_{2} \mathrm{O} 4: 1\right)$ showed complete deacetylation $(c a .24 \mathrm{~h})$. After evaporation and co-evaporation with $\mathrm{MeOH}(2 \times 5 \mathrm{ml})$, the remainder was dissolved in $\mathrm{MeOH}(5 \mathrm{ml})$ and the product precipitated by addition of $\mathrm{CHCl}_{3}: 5(590 \mathrm{mg}, 86 \%)$ as a white solid $\left(R_{\mathrm{f}}\left(\mathrm{MeCN} / \mathrm{H}_{2} \mathrm{O} 4: 1\right) 0.48\right) .{ }^{1} \mathrm{H}$ - and ${ }^{13} \mathrm{C}-\mathrm{NMR}$ : in agreement with those published [11].

$\mathrm{N}^{4}$-Benzoyl-2'-deoxy-5'-O- $\left(4,4^{\prime}\right.$-dimethoxytrityl $)-2^{\prime}$-fluorocytidine. Compound 5 was converted into $N^{4}$-benzoyl-2'-deoxy-2'-fluorocytidine according to the published procedure for the selective benzoylation of cytidine [25]. Purification was achieved by $\mathrm{FC}\left(\mathrm{CHCl}_{3} / \mathrm{MeOH} 95: 5 \rightarrow 90: 10\right)$ rather than trituration with $\mathrm{Et}_{2} \mathrm{O}$ due to partial solubility of the product in $\mathrm{Et}_{2} \mathrm{O}$. The resulting white solid $(488 \mathrm{mg}, 1.40 \mathrm{mmol})$ was dimethoxytritylated as described above for 2 to give the title compound ( $794 \mathrm{mg}, 87 \%$ ) as a white solid after lyophilization from benzene $\left(R_{f}\left(\mathrm{CHCl}_{3} / \mathrm{MeOH} 95: 5\right)\right.$ 0.18). ${ }^{1} \mathrm{H}-\mathrm{NMR}$ : in agreement with those published [11].

$\mathrm{N}^{4}$-Benzoyl-2'-deoxy-5'-O- $\left(4,4^{\prime}\right.$ dimethoxytrityl $)-2^{\prime}-$ fluorocytidine 3'-(2-Cyanoethyl Diisopropylphosphoramidite) (6). $N^{4}$-Benzoyl-2'-deoxy-5'-O-(4,4'-dimethoxytrityl)-2'-fluorocytidine $(788 \mathrm{mg}, 1.21 \mathrm{mmol})$ was reacted with (i-Pr) ${ }_{2} \mathrm{EtN}(621 \mu \mathrm{l}, 3.63 \mathrm{mmol})$ and $\mathrm{PCl}\left[\mathrm{N}(\mathrm{i}-\mathrm{Pr})_{2}\right]\left(\mathrm{OCH}_{2} \mathrm{CH}_{2} \mathrm{CN}\right)(405 \mu \mathrm{l}, 1.81 \mathrm{mmol})$ in anh. $\mathrm{CH}_{2} \mathrm{Cl}_{2}(4 \mathrm{ml})$ and purified under the same conditions as described above for 3 . Thus, $6(923 \mathrm{mg}, 90 \%)$ was obtained as a white solid after lyophilization from benzene $\left(R_{\mathrm{f}}\right.$ (toluene/AcOEt $\left.\left.1: 3\right) 0.31,0.43\right) .{ }^{31} \mathrm{P}-\mathrm{NMR}$ : in agreement with those published [11].

$C D$ Spectroscopy. The UV and CD spectra were measured in sodium-phosphate buffer (10 mM, $\mathrm{pH} 7.0$, $140 \mathrm{mM} \mathrm{NaCl}$ ) with an oligomer concentration of $10 \mu \mathrm{M}$.

NMR Spectroscopy. NMR Experiments were performed on Bruker-DRX400 and -DRX600 spectrometers equipped with quadruple $Q X I{ }^{1} \mathrm{H},{ }^{13} \mathrm{C},{ }^{19} \mathrm{~F},{ }^{31} \mathrm{P}$ probes. Spectra in $\mathrm{H}_{2} \mathrm{O} / \mathrm{D}_{2} \mathrm{O} 9: 1$ were run at $280 \mathrm{~K}$ and spectra in $\mathrm{D}_{2} \mathrm{O}$ at $300 \mathrm{~K}$. The sample concentration was $1 \mathrm{~mm}$, duplex concentration, therefore, $0.3 \mathrm{~mm}$ and hairpin concentration $0.7 \mathrm{~mm}$. Salt conditions were the same as for $\mathrm{CD} / \mathrm{UV}$ measurements. ${ }^{1} \mathrm{H},{ }^{13} \mathrm{C}-\mathrm{HSQC}$ Spectra were recorded with $4 \mathrm{k}$ complex data points in $t_{2}, 512$ real data points in $t_{1}$. For each fid, 144 scans were added. A recycle time of $1.5 \mathrm{~s}$ was used. ${ }^{1} \mathrm{H},{ }^{19} \mathrm{~F}$-HSQC Spectra were recorded with $2 \mathrm{k}$ complex data points in $t_{2}, 512$ real data points in $t_{1}$. For each fid, 8 scans were added. The recycle time was $1.5 \mathrm{~s}$. ROESY Experiments were performed employing a mixing time of $150 \mathrm{~ms}$ with $4 \mathrm{k}$ complex data points in $t_{2}, 768$ real data points in $t_{1}$. For each fid, 96 scans were added. A recycle time of $1.85 \mathrm{~s}$ was used.

NOESY Experiments were performed employing a mixing time of $300 \mathrm{~ms}$ with $4 \mathrm{k}$ complex data points in $t_{2}$. For the ${ }^{19} \mathrm{~F}$-half-filtered experiments, $4 \times 800$ real data points were collected in $t_{1}$. The four possible filter combinations (selection for ${ }^{19} \mathrm{~F}$ in $t_{1} / t_{2}$ ) were stored in subsequent fids. For each fid, 144 scans were added. A recycle time of $1.85 \mathrm{~s}$ was employed. For the ${ }^{1} \mathrm{H},{ }^{19} \mathrm{~F}$ HSQC-E.COSY, delays and phase cycling were chosen as follows: $\Delta^{\prime}=1 / 2 J_{(\mathrm{HF})}=9.43 \mathrm{~ms}, \mu_{1}= \pm 80, \mu_{2}=75.2 . \phi_{2}=x,-x ; \phi_{2}=x, x,-x,-x ; \phi_{3}=y, y,-y,-y$, $\phi_{\text {rec }}=x, x,-x,-x$. The spectrum was recorded with $4 \mathrm{k}$ complex data points in $t_{2}, 512$ real data points in $t_{1}$. For each fid, 128 scans were added. A recycle time of $1.5 \mathrm{~s}$ was used.

This work was supported by the Fonds der Chemischen Industrie and the DFG (B.R., K.W.). V.W. was funded by the 'Graduiertenkolleg Chemische und Biologische Synthese von Wirkstoffen' (Eg 52/3-3). H.S. is supported by the EU (ERBFMGECT 950034). The DFT calculations were kindly performed by Robert Havlin and Eric Oldfiled (work supported by NIH grants HL-19481 and GM-50694). All measurements have been performed at the large-scale facility 'Center for Biomolecular NMR at the University of Frankfurt'. W.B. thanks Dr. T. Keller for support.

\section{REFERENCES}

[1] R. Duschinsky, E. Pleven, C. Heidelberger, J. Am. Chem. Soc. 1957, 79, 4559.

[2] K. L. Kirk, 'Biochemistry of the Halogens', 'Biochemistry of Halogenated Organic Compounds', Plenum, New York, 1991, Vol. II.

[3] H.-O. Kalinowski, S. Berger, S. Braun, 'NMR-Spektroskopie von Nichtmetallen', "19 F-NMR Spektroskopie', Georg Thieme Verlag, Stuttgart-New York, 1994, Vol, IV.

[4] F. Rastinejad, P. Lu, J. Mol. Biol. 1993, 232, 105. 
[5] W.-C. Chu, V. Feiz, W. B. Derrick, J. Horowitz, J. Mol. Biol. 1992, 227, 1164.

[6] W.C. Chu, J. Horowitz, FEBS Lett. 1991, 295, 159.

[7] D. Parisot, M. C. Malet-Martino, R. Martino, P. Crasnier, Appl. Environ. Microbiol. 1991, 57, 3605.

[8] D. E. Bergstrom, A. W. Mott, E. De Clercq, J. Balzarini, D. J. Swartling, J. Med. Chem. 1992, $35,3369$.

[9] O. Heidenreich, F. Benseler, A. Fahrenholz, F. Eckstein, J. Biol. Chem. 1994, 269, 2131 ; M. Scherr, M. Grez, A. Ganser, J. W. Engels, ibid. 1997, 272, 14304.

[10] S. Schmidt, A. Niemann, N. F. Krynetskaya, T. S. Oretskaya, V. G. Metelev, V. V. Suchomlinov, Z. A. Shabarova, D. Cech, Biochim. Biophys. Acta 1992, 1130, 41.

[11] A. M. Kawasaki, M. D. Casper, S. M. Freier, E. A. Lesnik, M. C. Zounes, L. L. Cummins, C. Gonzalez, P. D. Cook, J. Med. Chem. 1993, 36, 831.

[12] E. Uhimann, A. Peyman, Chem. Rev. 1990, 90, 563.

[13] D. M. Cheng, L.-S. Kan, P. O. P. Ts'O, Biopolymers 1983, 22, 1427; M. Blandin, T.-D. Son, J. C. Cathlin, W. Guschlbauer, Biochim. Biophys. Acta 1974, 361, 249.

[14] D. Suck, W. Saenger, P. Main, G. Germain, J.-P. DeClercq, Biochim. Biophys. Acta 1974, $361,257$.

[15] W. Guschlbauer, M. Blandin, J. L. Drocourt, M. N. Thang, Nucleic Acids Res. 1977, 4, 1933; N. Kakiuchi, C. Marek, N. Rousseau, M. Leng, E. DeClercq, W. Guschlbauer, J. Biol. Chem. 1982, 257, 1924.

[16] M. Ikehara, Heterocycles 1984, 21, 75; W. Guschlbauer, K. Jankowski, Nucleic Acids Res. 1980, 8, 1421; W. K. Olson, J. L. Sussman, J. Am. Chem. Soc. 1982, 104, 270.

[17] G. Varani, B. Wimberly, I. Tinoco, Biochemistry 1989, 28, 7760; J. S. Puglisi, J. R. Wyatt, I. Tinoco, ibid. $1990,29,4215$.

[18] C.-H. Lee, I. Tinoco, Biophys. Chem. 1980, 11, 283; L. J. Ringel, C. Altona, J. Biomol. Struct. Dyn. 1987, 4, 621.

[19] S. G. Withers, I. P. Street, J. Am. Chem. Soc. 1988, $110,8551$.

[20] a) G. Varani, C. Cheong, I. Tinoco, Biochemistry 1991, 30, 3280; b) F. H.-T. Allain, G. Varani, J. Mol. Biol. $1995,250,333$.

[21] J. F. Codington, I. L. Doerr, J. J. Fox, J. Org. Chem. 1964, 29, 558.

[22] 'Oligonucleotides and Analogues: a Practical Approach', Ed. F. Eckstein, IRL Press, Oxford, 1991.

[23] I. L. Doerr, J. J. Fox, J. Org. Chem. 1967, 32, 1462.

[24] K. J. Divakar, C. B. Reese, J: Chem. Soc., Perkin Trans. 1 1982, 1171; B. F. L. Li, C. B. Reese, P. F. Swann, Biochemistry 1987, 26, 1086.

[25] V. Bhat, B. G. Ugarkar, V. A. Sayeed, K. Grimm, N. Kosora, P. A. Domenico, E. A. Stocker, Nucleosides Nucleotides 1989, 8, 179.

[26] J. S. Lucia, Jr., R. Kierzek, D. H. Turner, Biochemistry 1991, 30, 8242.

[27] C. Griesinger, O. W. Sørensen, R. R. Ernst, J. Am. Chem. Soc. 1985, 107, 6394; J. Chem. Phys. 1986, 85, 6837; J. Magn. Reson. 1987, 75, 474.

[28] A. A. Bothner-By, R. L. Stephens, J. Lee, C. D. Warren, R. W. Jeanloz, J. Am. Chem. Soc. 1984, 106, 811; A. Bax, D. G. Davis, J. Magn. Reson. 1985, 63, 207; C. Griesinger, R. R. Ernst, ibid. 1987, 75, 261; H. Desvaux, P. Berthault, N. Birlirakis, M. Goldman, M. Piotto, J. Magn. Reson., Ser. A 1995, 113, 47.

[29] D. J. Patel, S. A. Kozlowski, S. Ikuta, K. Itakura, FASEB J. 1984, 11, 2663.

[30] K. Wüthrich, 'NMR of Proteins and Nucleic Acids', Wiley, New York, 1986; J. Jenner, B. H. Meier, P. Bachmann, R. R. Ernst, J. Chem. Phys. 1979, 71, 4546.

[31] G. Otting, H. Senn, G. Wagner, K. Wüthrich, J. Magn. Reson. 1986, 70, 500; G. Otting, K. Wüthrich, ibid. 1989, 85, 586; G. Otting, K. Wüthrich, Q. Rev. Biophys. 1990, 23, 39.

[32] G. Varani, I. Tinoco, Q. Rev. Biophys. 1991, 24, 479.

[33] C. Griesinger, U. J. Eggenberger, J. Magn. Reson. 1992, 97, 426; U. Eggenberger, Y. Karimi-Nejad, H. Thüring, H. Rüterjans, C. Griesinger, J. Biomol. NMR 1992, 2, 583; H. B. Olsen, S. Ludvigsen, O. W. Sørensen, J. Magn. Reson., Ser. A 1993, 104, 226; H. Schwalbe, J. P. Marino, G. C. King, R. Wechselberger, W. Bermel, C. Griesinger, J. Biomol. NMR 1994, 4, 631.

[34] H. Schwalbe, J. P. Marino, S. J. Glaser, C. Griesinger, J. Am. Chem. Soc. 1995, 117, 7251; J. P. Marino, H. Schwalbe, S. J. Glaser, C. Griesinger, ibid. 1996, 118, 4388; S. J. Glaser, H. Schwalbe, J. P. Marino, C. Griesinger, J. Magn. Reson., Ser. B 1996, 112, 160.

[35] A. G. Palmer, J. Cavanagh, P. E. Wright, M. Rance, J. Magn. Reson. 1991, 93, 151; L. E. Kay, P. Keifer, T. Saarinen, J. Am. Chem. Soc. 1992, 114, 10663; J. Schleucher, M. Sattler, C. Griesinger, Angew. Chem., Int. Ed. Engl. 1993, 32, 1489; M. Sattler, M. G. Schwendinger, J. Schleucher, C. Griesinger, J. Biomol. NMR 1995, 5,11 . 
[36] R. Weisemann, H. Rüterjans, H. Schwalbe, J. Schleucher, W. Bermel, C. Griesinger, J. Biomol. NMR 1994, 4, 231.

[37] J. Schleucher, M. Schwendinger, M. Sattler, P. Schmidt, O. Schedletzky, S. J. Glaser, O. W. Sørensen, C. Griesinger, J. Biomol. NMR 1994, 4, 301.

[38] C. A. G. Haasnoot, F. A. A. M. de Leeuw, H. P. M. de Leeuw, C. Altona, Org. Magn. Reson. 1981, $15,43$.

[39] D. Neuhaus, M. Williamson, 'The Nuclear Overhauser Effect in Structural and Conformational Analysis', VCH, New York, 1989.

[40] R. Havlin, E. Oldfield, personal communication.

[41] A. M. Pyle, F. L. Murphy, T. R. Cech, Nature (London) 1992, 358, 123; S. A. Strobel, T. R. Cech, Nat. Struct. Biol. 1994, 1, 13.

[42] F. M. Jucker, H. A. Heus, P. F. Yip, E. H. M. Moors, A. Pardi, J. Mol. Biol. 1996, 264, 986; S. R. Lynch, J. G. Pelton, I. Tinoco, Magn. Reson. Chem. 1996, 34, 11.

[43] S. J. Rettig, J. Trotter, Acta Crystallogr., Sect. B 1974, 30, 2139; S. G. Withers, I. P. Street, S. J. Rettig, Can. J. Chem. 1986, 64, 232; P. E. Hansen, H. D. Dettman, B. D. Sykes, J. Magn. Reson. 1985, 62, 487; J. D. Dunitz, R. Taylor, Chem. - Eur. J. 1997, 3,89.

[44] T. Sakata, H. Hiroaki, Y. Oda, T. Tanaka, M. Ikehara, S. Uesugi, Nucleic Acids Res. 1990, 18, 3831; V. P. Antao, S. Y. Lai, I. Tinoco, ibid. 1991, 19, 5901; J. K. James, I. Tinoco, ibid. 1993, 21, 3287. 